\title{
Pieczęcie księżnej mazowieckiej Anny Radziwiłłówny z czasu jej regencji na Mazowszu w latach 1503-1518
}

Zarys treści: Artykuł poświęcony jest pieczęciom, którymi posługiwała się księżna mazowiecka Anna Radziwiłłówna, wdowa po Konradzie III Rudym, w czasie sprawowania rządów regencyjnych w imieniu swoich małoletnich synów - Stanisława i Janusza, w latach 1503-1518. W artykule zaprezentowano siedem pieczęci, w tym dwie dotychczas nieznane pieczęcie sygnetowe, należące wspólnie do księżnej i jej synów, pochodzące z krótkiego okresu ich współrządów (1517-1518). W opisie każdej z pieczęci zamieszczono informacje na temat jej kształtu, wymiarów, wyobrażeń i napisów napieczętnych oraz chronologii i przykładów użycia. Zanalizowano praktykę stosowania poszczególnych rodzajów pieczęci (osobista księżnej Anny, średnia herbowa zmarłego księcia, sygnety), wynikającą ze specyfiki rządów regencyjnych.

\begin{abstract}
The article presents the seals used by Duchess Anna Radziwiłł of Mazovia, the widow of Konrad III the Red, during her regency on behalf of her underage sons, Stanisław and Janusz, in 1503-1518. Seven seals are presented, including two previously unknown signet seals belonging jointly to the duchess and her sons, from the short period of their co-rule (1517-1518). The description of each seal contains information on their shape, dimensions, images and inscriptions together with their chronology and examples of use. The practice of using different types of seals (a personal of Duchess Anna, an armorial seal of the deceased duke, signet seals) is analysed, which resulted from the specificity of regency.
\end{abstract}

Słowa kluczowe: księżna Anna Radziwiłłówna, regencja, pieczęć sygnetowa, pieczęć herbowa, sfragistyka monarsza, Konrad III Rudy, Księstwo Mazowieckie

Keywords: Duchess Anna Radziwiłł, regency, signet seal, armorial seal, royal sigillography, Konrad III the Red, Duchy of Mazovia

Dobrą znajomość sfragistyki władców średniowiecznego Mazowsza zawdzięczamy monumentalnej pracy pióra Stefana K. Kuczyńskiego ${ }^{1}$. Zawiera ona gruntowne omówienie pieczęci stosowanych przez Piastów mazowieckich oraz ich katalog, począwszy od sigillów Konrada I z początku XIII w. po pieczęcie ostatniego księcia mazowieckiego Janusza III z okresu jego samodzielnych rządów w latach 1524-1526. W sumie katalog ten obejmuje ponad 80 pozycji, zgromadzonych w toku wieloletnich poszukiwań w archiwach i bibliotekach polskich i zagranicznych. Kwerendy archiwalne prowadzone w ciągu ponad 40 lat, które upłynęły od ukazania się tej publikacji, przyniosły jednak nowe odkrycia. Znalazły się wśród nich zarówno odciski pieczętne znane wspomnianemu badaczowi jedynie z opisów

${ }^{1}$ S.K. Kuczyński, Pieczęcie książąt mazowieckich, Wrocław 1978. 
źródłowych ${ }^{2}$, jak i nieznane odciski (lub ich opisy) pieczęci już przez niego odkrytych ${ }^{3}$. Trzecią grupę, najistotniejszą z punktu widzenia rozwoju badań sfragistycznych, stanowią sigilla Piastów mazowieckich, do których S.K. Kuczyńskiemu nie udało się dotrzeć4. Przedmiotem niniejszego artykułu są pieczęcie, którymi posługiwała się księżna Anna Radziwiłłówna w czasie, gdy przez niemal 15 lat sprawowała rządy regencyjne w imieniu małoletnich synów - Stanisława i Janusza Konradowiców. Omówione zostaną nie tylko osobiste pieczęcie księżnej, lecz również te odziedziczone po zmarłym mężu Konradzie III, których używała z racji sprawowanej funkcji opiekunki i regentki Księstwa. Sigilla te zostały skatalogowane i opisane przez S.K. Kuczyńskiego5. Lektura zapisów z metryki książęcej i koronnej oraz mazowieckich ksiąg ziemskich, a przede wszystkim analiza korespondencji księżnej i jej synów prowadzonej z zakonem krzyżackim w latach 1511-1525, tj. w tej części działu Ordensbriefarchiv (OBA) przechowywanego obecnie w Geheimes Staatsarchiv Preußischer Kulturbesitz w Berlin-Dahlem (GStA PK), która nie została objęta poszukiwaniami S.K. Kuczyńskiego, pozwoliły jednak w istotny sposób na uzupełnienie ustaleń tego wybitnego badacza na temat liczby pieczęci stosowanych przez księżną Annę oraz na dokładniejszą (bądź odmienną) interpretację pieczęci przez niego odkrytych. Przyniosły m.in. odkrycie nieznanych dotąd dwóch pieczęci sygnetowych, używanych przez księżną Annę Radziwiłłównę i jej synów w czasie ich wspólnych rządów trwających od wczesnej wiosny 1517 do pierwszych miesięcy 1518 r. Dzięki odnalezieniu nowych odcisków udało się też przesunąć chronologię używania przez Annę jej osobistej pieczęci herbowej wykonanej na potrzeby regencji.

Anna, księżna mazowiecka, była córką wojewody wileńskiego i kanclerza wielkiego litewskiego Mikołaja Radziwiłłowicza i jego pierwszej żony Zofii Moniwidówny, wojewodzianki wileńskiej ${ }^{6}$. Między 29 IX 1496 a 25 I 1497 została trzecią żoną Konrada III Rudego7. Po jego śmierci 28 X 1503, zgodnie

${ }^{2}$ M. Hlebionek, Nieznana pieczęć księcia Kazimierza II przy dokumencie pokoju brzeskiego z 1435 r., w: Dziedzictwo ksiażą mazowieckich. Stan badań i postulaty badawcze. Materiały z sesji naukowej zorganizowanej przez Zamek Królewski w Warszawie - Muzeum i Archiwum Główne Akt Dawnych, 27-28 października 2016 r., red. J. Grabowski, R. Mroczek, P. Mrozowski, Warszawa 2017, s. 263-271.

3 Weryfikacji niektórych ustaleń S.K. Kuczyńskiego dokonał J. Grabowski, omawiając tytulaturę władców Mazowsza. Na podstawie niewykorzystanych wcześniej źródeł udało mu się m.in. przesunąć czas użycia pieczęci herbowej Siemowita III oraz zrekonstruować brzmienie napisu na pieczęci herbowej II większej Siemowita IV, dowodząc, że zawierał on też tytuł płocki; tenże, Dynastia Piastów mazowieckich. Studia nad dziejami politycznymi Mazowsza, intytulacją i genealogia książat, Kraków 2012, s. 268-390, tu s. 296, 317 n., 325; zob. też S. Szybkowski, Listy książą mazowieckich do gdańskiej rady miejskiej (do końca wojny trzynastoletniej), „Archeion”, 113, 2012, s. 244, regest nr 11 (odcisk pieczęci herbowej średniej Władysława I na liście z 25 IX 1443); tenże, Korespondencja ksiażą mazowieckich z rada miasta Gdańska w latach 1466-1526, w: Dziedzictwo książąt mazowieckich, s. 301 n. (odcisk pieczęci herbowej Anny Radziwiłłówny z 1516 r.).

${ }^{4}$ J. Pakulski, Zaginiona pieczęć księżnej Perejasławy z 1276 r. a trzynastowieczne sigilla księżnych Polski dzielnicowej, w: Nihil superfluum esse. Prace z dziejów średniowiecza ofiarowane Profesor Jadwidze Krzyżaniakowej, red. J. Strzelczyk, J. Dobosz, Poznań 2000, s. 247-262; zob. też J. Grabowski, Dynastia Piastów mazowieckich, s. 271; Ł. Włodarski, Nieznana pieczęć biskupa płockiego Henryka Siemowitowica z 1391 r., w: Dziedzictwo książat mazowieckich, s. 253-261; J.W. Woś, Alessandro di Masovia, vescovo di Trento e patriarca di Aquileia (1400-1444), Roma-Trento 1998, s. 28, 79; J. Grabowski, Dynastia Piastów mazowieckich, s. 328 (pieczęć Aleksandra Siemowitowica, biskupa trydenckiego, od 1424 r.); S. Szybkowski, Korespondencja książą mazowieckich, s. 302 (nieznana dotąd II pieczęć sygnetowa Konrada III; zob. też dalej); J. Grabowski, Anna Odrowążowa, ostatnia księżna mazowiecka, „Archeion”, 113, 2012, s. 277 oraz Aneks 2, s. 281; tenże, Dynastia Piastów mazowieckich, s. 390 (pieczęć sygnetowa Anny Konradówny, żony Stanisława ze Sprowy wojewody ruskiego, z czasu po inkorporacji Mazowsza do Korony w 1526 r.).

${ }^{5}$ S.K. Kuczyński, Pieczęcie książat mazowieckich, s. 386-388.

${ }^{6}$ O. Halecki, Anna z Radziwiłłów (1476-1522), księżna mazowiecka, w: PSB, t. 1, Kraków 1935, s. 125 n.; K. Pietkiewicz, Radziwiłt (Radziwiłłowicz) Mikołaj h. Trąby (zm. 1509), kasztelan trocki, wojewoda wileński, kanclerz wielki litewski, w: PSB, t. 30, Wrocław 1987, s. 315 n.; M. Antoniewicz, Protoplaści książąt Radziwiłłów. Dzieje mitu i meandry historiografii, Warszawa 2011, s. 30, tab. 1: Rodowód najdawniejszych pokoleń rodu Radziwiłłów i rodzin spokrewnionych; zob. też Radziwitłowie herbu Trąby, red. S. Górzyński [i in.], Warszawa 1996.

7 B. Sobol, Konrad III (ok. 1448-1503), ksiązę mazowiecki, w: PSB, t. 13, Poznań-Wrocław 1967-1968, s. 595-597; K. Jasiński, Rodowód Piastów mazowieckich, wyd. M. Górny, Poznań-Wrocław 1998 [recte: 2008], s. 172; J. Grabowski, Małżeństwa Konrada III Rudego. Ze studiów nad genealogia Piastów mazowieckich, w: Klio viae et invia. Opuscula Marco Cetwiński dedicata, red. A. Odrzywolska-Kidawa, Warszawa 2010, s. 801-803; tenże, Dynastia Piastów mazowieckich, s. $483 \mathrm{n}$. 
z obowiązującym na Mazowszu prawem zwyczajowym, objęła rządy w imieniu swoich małoletnich synów Stanisława i Janusza. Formalnie księżną Annę jako opiekunkę książąt i regentkę Mazowsza zatwierdził i ustanowił król Aleksander Jagiellończyk na sejmie w Radomiu 1 VI $1505^{8}$. Anna, używająca tytułu dux et tutrix Masovie ${ }^{9}$, rządzić miała jedynie czasowo, do momentu osiągnięcia przez starszego z synów - Stanisława - wieku sprawnego do wykonywania samodzielnie władzy, tj. do ukończenia przez niego 15 lat, co nastąpiło w maju 1516 r. ${ }^{10}$ Regentka nie chciała jednak przekazać steru rządów, co spotkało się ze sprzeciwem części szlachty, który w lipcu 1516 r. przybrał zbrojną formę. Pod wpływem nacisku ze strony króla polskiego Zygmunta I oraz w obliczu groźby zaostrzenia konfliktu i rozprzestrzenienia się go na całe Księstwo, księżna dopuściła synów do władzy wiosną 1517 r. Wspólne rządy książąt Anny, Stanisława i Janusza trwały przez niecały rok, do lutego 1518 r. Radziwiłłówna została wówczas odsunięta od władzy, co zatwierdził wyrok królewski z $14 \mathrm{~V} \mathrm{1518,} \mathrm{a} \mathrm{jego} \mathrm{postanowienia} \mathrm{przyjął}$ następnie mazowiecki sejm generalny, obradujący w Zakroczymiu latem tegoż roku ${ }^{11}$.

W czasie swego krótkiego małżeństwa z Konradem III księżna Anna posługiwała się osobistą pieczęcią herbową zamówioną i wykonaną zapewne wkrótce po ślubie ${ }^{12}$. Znana jest ona obecnie tylko z jednego odcisku (na podkładzie z czerwonego wosku przez papier), zachowanego na liście kredencyjnym Anny dla Jana z Krakowa, prepozyta szpitala św. Marcina i mansjonarza kolegiaty św. Jana Chrzciciela w Warszawie, skierowanym do wielkiego mistrza krzyżackiego Fryderyka Wettina 4 XII 1503 (il. 1) ${ }^{13}$. Wizerunek napieczętny zachował się dość wyraźnie i przedstawia orła bez korony na tarczy. Szeroka, u dołu półokrągła tarcza wypełnia niemal całe pole pieczęci. Niewielką wolną przestrzeń między tarczą a otokiem wypełniono falistym ornamentem. Orła przestawiono z szeroko rozpostartymi skrzydłami i ogonem, dbając też o detale: wysunięty, zakręcony jęzor i potężne pazury. Dużo mniej czytelna jest natomiast legenda, ostatnia jej część jest poważnie zatarta ${ }^{14}:{ }^{*} \mathrm{~S} *$ ANNE * DUCISSE * [MAZO]VIE. Inskrypcję wykonano pismem gotyckim: $\mathrm{S}$ - majuskułą, resztę - minuskułą ${ }^{15}$. Umieszczono ją na wstędze ze zwijającymi się końcami. Dywizory między wyrazami mają kształt rozetek. Na podstawie fragmentarycznie zachowanej końcówki legendy przyjmujemy, że zastosowano tu tytulaturę ogólnomazowieckąa ${ }^{16}$. Pieczęć była okrągła, średniej wielkości - jej średnica wynosiła $30 \mathrm{~mm}$. Formuła sigillacyjna tej pieczęci nie jest znana, nie zachowały się bowiem żadne dokumenty księżnej Anny z czasu jej małżeństwa z Konradem III. Wspomniany wyżej odcisk pochodzi z okresu już po jego śmierci, a zatem sigillum było w użyciu Anny dowodnie jeszcze na początku jej rządów opiekuńczych, przypuszczalnie do czasu sporządzenia dla niej nowej pieczęci, bardziej okazałej i odpowiedniej dla jej roli i pozycji regentki, uwzględniającej przyjętą w tym okresie tytulaturę.

\footnotetext{
${ }^{8}$ Iura Masoviae terrestria, t. 2: 1471-1526, oprac. J. Sawicki, Warszawa 1973 [dalej: IMT 2], nr 179; M. Piber-Zbieranowska, A. Supruniuk, Regencja Anny Radziwiłtówny na Mazowszu w latach 1503-1518: zarys problematyki, Przegl. Hist., 106, 2015, nr 2, s. 325-345.

${ }^{9}$ O tytulaturze używanej przez księżną Annę w czasie rządów regencyjnych i po ich zakończeniu zob. M. Piber-Zbieranowska, Księżna mazowiecka Anna Radziwitłówna i jej regencja na Mazowszu (1503-1518), Warszawa 2019, mszp. rozprawy doktorskiej przyg. pod kier. M. Koczerskiej, Biblioteka IH PAN w Warszawie, s. 270-288.

${ }^{10}$ W Księstwie Mazowieckim istniały dwa stopnie uzyskania pełnoletności przez książąt: aetas legitima, a następnie aetas debita; taż, Żony Piastów mazowieckich. Znaczenie polityczne księżnych w późnym średniowieczu (XIV-XVI w.), w: Dziedzictwo książą mazowieckich, s. 134 n. Stanisław urodził się 17 V 1501; Księga radziecka miasta Starej Warszawy, t. 1: 1447-1527, wyd. A. Wolff, Wrocław 1963, s. XIX; zob. też K. Pacuski, Stanisław (1501-1524), ksiązę mazowiecki, w: PSB, t. 42, Warszawa-Kraków 2003-2004, s. 1-3.

${ }^{11}$ IMT 2, nr 208; B. Sobol, Sejm i sejmiki ziemskie na Mazowszu książęcym, Warszawa 1968, s. 129-133.

12 S.K. Kuczyński, Pieczęcie książąt mazowieckich, s. 236 oraz 386, nr 75; za S.K. Kuczyńskim przyjmuję określenie omawianej pieczęci jako ,pieczęć herbowa I”.

13 Geheimes Staatsarchiv Preußischer Kulturbesitz, Berlin-Dahlem, XX HA, Ordensbriefarchiv [dalej: GStA PK, OBA], nr 18848.

${ }_{14}$ Transkrypcji inskrypcji napieczętnych dokonano wedle instrukcji zawartej w: Vocabularium internationale sigillographicum, red. K. Müller, L. Vrtel, M. Hlebionek, V. Keresztes, tłum. pol. B. Jusypenko, oprac. M. Hlebionek, A. Baniecki, D. Bednarek, R. Forysiak-Wójciński, J. Grabowski, P. Gut, P. Pokora, D. Żygadło, Bratislava 2016, s. 71-73.

15 O stosowaniu majuskuły i minuskuły w sfragistyce książąt mazowieckich zob. S.K. Kuczyński, Pieczęcie książąt mazowieckich, s. 208-210.

${ }^{16}$ Por. J. Grabowski, Dynastia Piastów mazowieckich, s. 384.
} 
Nie wiemy, kiedy dokładnie kolejna pieczęć regentki została wykonana i wprowadzona do użytku. Najwcześniejszy znany, niebudzący wątpliwości jej odcisk pochodzi dopiero z 5 VI $1506^{17}$. Przypuszczać można, że księżna sprawiła sobie ją już w początkach 1504 r. Nie jest jednak wykluczone, że ze sporządzeniem nowego tłoku czekano do czasu formalnego ustanowienia księżnej Anny opiekunką małoletnich książąt przez króla w połowie 1505 r. ${ }^{18}$ Tym bardziej że po zawarciu w marcu $1504 \mathrm{r}$. układu z Aleksandrem Jagiellończykiem dotyczącego posiadania Księstwa Mazowieckiego przez małoletnich Konradowiców na prawach lenna, dziedziczonego wzajemnie po sobie ${ }^{19}$, księżna miała początkowo sprawować rządy opiekuńcze nie samodzielnie, lecz przy wsparciu czterech tutorów, a stan państwa po upływie określonego przez króla czasu ocenić mieli jego wysłannicy. Dopiero na podstawie ich pozytywnego osądu król oficjalnie powierzył księżnej opiekę i sprawowanie władzy w imieniu synów ${ }^{20}$.

Przesłanką do przyjęcia późniejszej datacji może być użycie przez Annę do uwierzytelnienia listu do wielkiego mistrza z 14 VII 1505, jak sądzę, pieczęci średniej swego zmarłego męża ${ }^{21}$. Do poglądu, że na liście tym widnieje odcisk pieczęci herbowej Konrada III, skłaniał się S.K. Kuczyński, podkreślając jednocześnie, że stan zachowania tegoż odcisku nie pozwala na jednoznaczne stwierdzenie, której pieczęci wówczas użyto ${ }^{22}$. Istotnie, pieczęć została pierwotnie słabo odciśnięta, co powoduje, że obraz jest obecnie mało czytelny. Na odcisku są jednak nadal widoczne elementy wizerunku napieczętnego zawierającego tarczę czwórdzielną w krzyż, a pieczęcią z takim wizerunkiem posługiwał się, aż do swej śmierci, Konrad III. Została ona następnie przejęta przez wdowę po nim - księżną Annę ${ }^{23}$, dlatego też poświęcę jej więcej miejsca w dalszej części tekstu. Tu zasygnalizuję jedynie, że cechą charakterystyczną przedstawienia tegoż sigillum, odróżniającą je od obu pieczęci Anny Radziwiłłówny, była gotycka tarcza, której dolny brzeg wkomponowany był we wstęgę z legendą, przedzielając ją na dwie częśsi ${ }^{24}$, co dostrzec można wyraźnie i na omawianym odcisku. Wydaje się zatem dopuszczalne przyjęcie hipotezy, że w lipcu 1505 r. Anna nie dysponowała jeszcze nową pieczęcią osobistą, odzwierciedlającą jej ówczesną pozycję, stąd też, pisząc do wielkiego mistrza z prośbą dotycząca ogółu jej poddanych, posłużyła się pieczęcią średnią zmarłego męża, która znacznie lepiej podkreślała rangę wystosowanego pisma niż używane zwykle do opatrzenia jej wcześniejszej korespondencji pieczęcie sygnetowe ${ }^{25}$.

${ }^{17}$ AGAD, Zbiór dokumentów pergaminowych [dalej: perg.], nr 662; wyd.: Wzory pism dawnych w przerysach wystawione i objaśnione drukowanem ich wyczytaniem, cz. 1: 1228-1536, wyd. K. Stronczyński, Warszawa 1839, nr 87, s. 95 (z lakonicznym opisem przywieszonej pieczęci).

18 S.K. Kuczyński, odnotowując fakt, że pierwszy znany odcisk omawianej pieczęci pochodzi z połowy 1506 r., przyjmował, że „prawdopodobnie została wprowadzona już wcześniej, być może w końcu 1503 r. [...] lub na początku 1504 r., ale na pewno po 4 XII 1503 r.” Badacz ten przypuszczał też, że księżna opieczętowała nią list do króla rzymskiego Maksymiliana I Habsburga z 5 I 1505; tenże, Pieczęcie książat mazowieckich, s. 387. Opis cech zewnętrznych listu, znajdującego się w Landesregierungsarchiv w Innsbrucku, sporządził jego wydawca - M. Biskup, który podał, że na dole wspomnianego listu znajdują się „ślady pieczęci w czerwonym wosku o średnicy $32 \mathrm{~mm}$ ”; tenże, Materiaty do stosunków habsbursko-mazowieckich na przełomie XV-XVI w. w archiwach austriackich, Przegl. Hist., 59, 1968, nr 2, s. 278. Moim zdaniem wymiary śladu wskazują raczej na użycie tu innej pieczęci, o mniejszej średnicy, być może tej, która używana była przez księżną od czasu zawarcia małżeństwa.

19 IMT 2, nr 171, 172.

${ }^{20}$ Zagadnienia te, niepodnoszone w dotychczasowych badaniach, omówione są szerzej w: M. Piber-Zbieranowska, Księżna mazowiecka Anna Radziwitłówna, s. 74-91.

${ }^{21}$ GStA PK, OBA, nr 19019.

22 S.K. Kuczyński, Pieczęcie książąt mazowieckich, s. 376, przyp. 5.

${ }^{23}$ Tamże, s. 54, 57.

${ }^{24}$ AGAD, perg. nr 1537, Dokument Konrada III dla rajców i mieszczan Starej Warszawy, 28 VII 1494; wizerunek dostępny on-line: <https://szukajwarchiwach.pl/1/1/0/-/1537\#tabSkany> [dostęp: 22.03.2020].

${ }^{25}$ W liście z 14 VII 1505 księżna prosiła wielkiego mistrza Fryderyka, by zabronił swoim urzędnikom pobierać w Ostródzie cło novum et inconsvetum, niesłusznie nakładane na jej poddanych, przede wszystkim kupców z Ciechanowa i Przasnysza, dając mu do zrozumienia, że w przypadku, gdy opłaty nadal będą egzekwowane, będzie zmuszona to samo uczynić w stosunku do poddanych krzyżackich; GStA PK, OBA, nr 19019. Cztery listy do Fryderyka Wettina, napisane w okresie od stycznia do czerwca 1504 r., Anna opieczętowała sygnetem swego męża, dotyczyły one jednak bądź sfery prywatnej księżnej, bądź spraw partykularnych jej poddanych; GStA PK, OBA, nr 18879, 18905, 18910, 18916. 
Nowa pieczęć osobista księżnej Anny, za S.K. Kuczyńskim przyjmuję dla niej określenie „herbowa II”26, była większa od poprzedniej, jej średnica wynosiła $34 \mathrm{~mm}$ (il. 2). Przedstawienie napieczętne było zaś analogiczne: orzeł bez korony na tarczy ${ }^{27}$. Wprowadzono jednak na nim więcej elementów ozdobnych - całą przestrzeń między krawędzią tarczy a polem legendy wypełniono falistym, stylizowanym ornamentem roślinnym, który nad górną krawędzią tarczy osadzono w równoległej do niej ciągłej linii. Tarcza miała identyczny kształt jak na pieczęci herbowej I. Sylwetce orła nadano natomiast większą lekkość z dbałością o zaznaczenie szczegółów: piór na rozpostartych skrzydłach, rozsuniętych pazurów i finezyjnie podkręconego po obu stronach ogona ${ }^{28}$. Pomiędzy dwoma liniami otokowymi (zewnętrzną podwójną ciągłą, wewnętrzną pojedynczą) umieszczono wykonaną pismem gotyckim legendę: * $\mathrm{S} *$ ANNE * DEI G $($ racia $) *$ DUCIS * MAZOVIE * RUSSIE * ET $($ c $)$. Litera S rozpoczynająca inskrypcję była majuskulna, resztę zaś sporządzono minuskułą. Uwagę zwraca jednak litera „s” na końcu słowa ducis, nieco większa w rozmiarze od pozostałych. Chodziło zapewne o podkreślenie, że nie jest to skrót słowa ducisse, jak na poprzednio używanej pieczęci, lecz dopełniacz tytułu dux, którym regentka posługiwała się od momentu objęcia rządów opiekuńczych ${ }^{29}$. Dywizorom nadano kształt gwiazdek ${ }^{30}$. W zachowanych źródłach na opisanie tejże pieczęci używano sformułowania sigillum mediocre ${ }^{31}$ lub sigillum ducale $e^{32}$.

Największe zmiany wprowadzono zatem w tytulaturze umieszczonej na nowej pieczęci, przede wszystkim dodając do niej formułę dewocyjną. Użycie formuły Dei gracia miało bez wątpienia podkreślić monarszy i suwerenny charakter władzy sprawowanej przez księżną Annę jako regentkę. Wedle ówczesnych przekonań formuła ta miała, poza znaczeniem prestiżowym, także i wymiar rzeczywisty - oznaczała bowiem, że władza stosującego ją monarchy opiera się na sakralnych podstawach i wykonywana jest z boskiego namaszczenia. Wyrażała zatem charyzmatyczny charakter tej władzy ${ }^{33}$.

${ }^{26}$ S.K. Kuczyński, Pieczęcie książąt mazowieckich, s. 387-389, nr 76.

${ }^{27} \mathrm{~W}$ czasie swoich rządów również inne mazowieckie księżne regentki (Barbara Aleksandrówna) używały wizerunku orła bez korony, symbolu dynastii Piastów mazowieckich i całego Mazowsza; tamże, s. 169, 174.

${ }^{28}$ S.K. Kuczyński stwierdził, że sylwetka orła na tej pieczęci „zdradza już wyraźne znamiona rodzącego się stylu renesansowego - jest on [...] miękko modelowany przy pomocy delikatnie prowadzonych po krzywiznach cięć rylca"; tamże, s. 236.

${ }^{29}$ Męska forma tytułu książęcego - dux - wprowadzona do swej tytulatury przez Annę Radziwiłłównę była absolutnym novum. Nie używała go do tej pory żadna z regentek mazowieckich; szerzej o tym: M. Piber-Zbieranowska, A. Supruniuk, Die Legitimierung der Herrschaft in Masowien im Lichte der Urkunden und Korrespondenz der masowischen Herzogin Anna Radziwitlówna, w: Legitimation von Fürstendynastien in Polen und dem Reich. Identitätsbildung im Spiegel schriftlicher Quellen (12.-15. Jahrhundert), red. G. Vercamer, E. Wółkiewicz, Wiesbaden 2016, s. 328-335; M. Piber-Zbieranowska, Księżna mazowiecka Anna Radziwiłłówna, s. 279-284, 287-290. O tym, że działanie księżnej regentki było nietypowe i nie mieściło się w znanej dotąd praktyce, świadczyć może propozycja wysunięta przez S.K. Kuczyńskiego, by widniejący na pieczęci Anny Radziwiłłówny tytuł ducis traktować jako „,nie zaznaczony skrót właściwego tu brzmienia ducisse”; tenże, Pieczęcie książąt mazowieckich, s. 185.

${ }^{30}$ AGAD, perg. nr 662, 1545.

31 AGAD, MK 45, k. 21.

${ }^{32}$ AGAD, MK 340, k. 20. Jest to list księżnej Anny do biskupa poznańskiego Jana Lubrańskiego z 27 IX 1514, w którym potwierdza ona swoją zgodę na kandydaturę Jakuba Kuli na wakującą prepozyturę w kościele św. Jerzego w Warszawie, na podstawie wyboru dokonanego przez konwent kanoników regularnych z Czerwińska, i prosi biskupa o potwierdzenie prezenty i inwestyturę Jakuba. List zachował się dzięki wpisowi do metryki książęcej. W sposób nietypowy dla listów w jego treści zawarto formułę sigillacyjną w brzmieniu: „In cuius rei testimonium sigillum nostrum ducalem quo in talibus utimur presentibus est appensum". O formularzu listów wychodzących z kancelarii polskich władców zob. S. Szybkowski, Listy książą mazowieckich, s. 230-236; W. Szczuczko, List królewski z przełomu wieków XV i XVI w zbiorach Archiwum Państwowego w Toruniu, „Archeion”, 113, 2012, s. 249-262.

${ }^{33}$ Formułę Dei gracia jako element legendy pieczęci książąt mazowieckich omówił S.K. Kuczyński (tenże, Pieczęcie książąt mazowieckich, s. 183 n.), jej funkcje w tytulaturze książęcej przedstawił zaś, z uwzględnieniem najnowszej literatury, J. Grabowski (tenże, Dynastia Piastów mazowieckich, s. 265-267). O jej znaczeniu w użyciu księżnych regentek zob. M. Piber-Zbieranowska, Le rôle politique des duchesses de Mazovie au bas Moyen Age, w: La femme dans la société médiévale et moderne [Actes du colloque de Nieborów 6-8 juin 2002], red. P. Mane, F. Piponnier, M. Wilska, M. Piber-Zbieranowska, Varsovie 2005, s. 108 n.; A. Muszyńska, Ideologia władzy w sfragistyce polskich księżnych sprawujących rządy opiekuńcze na wybranych trzynastowiecznych przykładach, w: Ideologia i rytuały władzy w średniowieczu. Materiały studencko-doktoranckiej konferencji naukowej, Uniwersytet Warszawski, 15-16 maja 2010, red. P. Figurski i in., Warszawa 2011, s. 53-62. 
Znacząca zmiana zaszła także w tytułach księżnej. O ile na wcześniejszej pieczęci Anna używała tytułu ducissa, adekwatnego do jej pozycji księżnej żony, o tyle na pieczęci księżnej regentki tytułowała się jako dux. Nowym dodatkiem była tytulatura ruska, przejęta zapewne z pieczęci Konrada III ${ }^{34}$. Oba te elementy występowały w tytulaturze stosowanej przez księżną w dokumentach i korespondencji z omawianego okresu: Anna Dei gracia dux et tutrix Masovie, Russie etc.

Omawiane sigillum było osobistą pieczęcią księżnej regentki. Anna Radziwiłłówna używała jej wyłącznie do uwierzytelniania dokumentów o charakterze doczesnym wystawianych samodzielnie, we własnym imieniu (bez udziału małoletnich synów lub tutorów i innych członków rady książęcej), zaopatrzonych zazwyczaj w formułę comissio propria domine ducis ${ }^{35}$. Do dziś zachowały się zaledwie dwa odciski pieczęci herbowej II przy dokumentach wydanych przez Annę, z 5 VI 1506 i 30 XII 1509. W obu przypadkach pieczęć została odciśnięta w czerwonym wosku i, po umieszczeniu w misce z bezbarwnego wosku, zawieszona na pasku pergaminowym ${ }^{36}$. Na dokumencie z 2 VI 1516 natomiast widoczne są jedynie nacięcia po tego rodzaju paskư ${ }^{37}$.

Pieczęcią herbową II księżna posługiwała się również w swojej korespondencji. Sigillum spełniało wówczas dwie funkcje: bądź do zamknięcia listu (strzegło tajemnicy korespondencji), bądź jako środek uwierzytelniania treści (listy kredencyjne) ${ }^{38}$. Fakt używania przez księżną pieczęci osobistej w korespondencji jedynie podejrzewał S.K. Kuczyński ${ }^{39}$. Nie udało mu się dotrzeć do żadnych jej odcisków zachowanych na listach Anny Radziwiłłówny, w tym do znajdujących się w zespole Ordensbriefarchiv, który gromadzi korespondencję pochodzącą z zasobu byłego archiwum zakonu krzyżackiego. Pierwotnie archiwalia te znajdowały się w zbiorach Staatsarchiv w Królewcu, następnie (od 1953) w Staatliches Archivlager w Getyndze, a obecnie przechowywane są w Geheimes Staatsarchiv Preußischer Kulturbesitz w Berlin-Dahlem. Poszukiwania S.K. Kuczyńskiego w zasobie OBA (przeprowadzone jeszcze w Getyndze) objęły bowiem jedynie materiał do 1510 r. włącznie, ponieważ taką cezurę czasową ma drugi tom regestów wydanych przez Ericha Joachima i Walthera Hubatscha ${ }^{40}$, który dostępny był w czasie, gdy Profesor prowadził swoje badania. Zaznaczyć trzeba, że przejrzenie przez jedną osobę, w ograniczonym czasie przeznaczonym na zagraniczną kwerendę, pozostałej zawartości tego zespołu, tj. z lat 1511-1525, bez pomocy Regesta historico-diplomatica Ordinis S. Mariae Theutonicorum jest praktycznie niemożliwe, gdyż obejmuje on ponad 8200 listów. W 1973 r. ukazał się trzeci tom tegoż wydawnictwa, co umożliwiło mi przeprowadzenie poszukiwań w niewykorzystanym dotąd materiale ${ }^{41}$. Udało mi się odnaleźć osiem odcisków omawianego sigillum. Uwierzytelnione nim listy, wystosowane

${ }^{34}$ S.K. Kuczyński, Pieczęcie książąt mazowieckich, s. 372-375, nr 63, 64 (o tytulaturze ruskiej na pieczęciach książąt mazowieckich zob. tamże, s. 197-199). Zagadnienie to w praktyce kancelarii książąt mazowieckich omawia J. Grabowski, Tytulatura na dokumentach książą mazowieckich. Forma i funkcje (wybrane zagadnienia), „Klio”, 13, 2009, s. 59-66; zob. też A. Swieżawski, Tytulatura ruska książąt mazowieckich, Częstochowa 1994.

35 AGAD, perg. nr 1545, 1549, 3686; AGAD, Zakroczymskie ziemskie wieczyste relacje [dalej: Zakr.] 20, k. 335; S.K. Kuczyński, Pieczęcie książąt mazowieckich, s. 58, 388. Niekiedy jednak dokumenty opatrzone tą formułą księżna uwierzytelniała pieczęcią sygnetową (AGAD, MK 340, k. 48), a w jednym znanym przypadku pieczęcią średnią swego męża (AA Poznań, Acta episcopalia V, k. 96); zob. dalej.

${ }^{36}$ AGAD, perg. nr 662, 1545. Odcisk z późniejszego chronologicznie dokumentu (nr 1545) jest gorzej zachowany - ma jedno większe pęknięcie przez środek i drugie, mniejsze, z lewej (heraldycznie) strony u góry; litery w legendzie są częściowo zatarte. Skan tego dokumentu (wraz ze zdjęciem zachowanej pieczęci) dostępny jest on-line: <https://szukajwarchiwach. pl/1/1/0/-/1545\#tabSkany> [dostęp: 10.03.2020].

37 AGAD, perg. nr 1549; o użyciu przez księżną Annę swej osobistej pieczęci świadczyć może brzmienie formuły sigillacyjnej: „Harum quibus sigillum nostrum, quo utimur, est subappensum testimonio litterarum”. Pieczęci brak też przy czwartym zachowanym w oryginale dokumencie ks. Anny (z 28 XII 1514), który jest w tym miejscu uszkodzony, wykazując spore ubytki (AGAD, perg. 3686; formuła sigillacyjna w brzmieniu: ,in cuius rei testimonium sigillum nostrum ducale, quo utimur, presentibus est appensum").

${ }^{38}$ W. Szczuczko, List królewski, s. 255; E. Kozaczkiewicz, Trzy pieczęcie Jana Długosza, St. Źródł., 56, 2018, s. 129.

39 S.K. Kuczyński, Pieczęcie książą mazowieckich, s. 388.

${ }^{40}$ Regesta historico-diplomatica Ordinis S. Mariae Theutonicorum, cz. 1: Regesten zum Ordensbriefarchiv, t. 2: 1455-1510, oprac. E. Joachim, wyd. W. Hubatsch, Göttingen 1950.

${ }^{41}$ Tamże, t. 3: 1511-1525, Göttingen 1973. Obecnie regesty te (z opcją wyszukiwania) dostępne są na stronie GStA PK, $<$ https://www.gsta.spk-berlin.de/archivdatenbank_1522.html> [dostęp: 21.03.2020]. 
przez księżną Annę Radziwiłłównę, samą bądź (w jednym wypadku) wspólnie z synami, pochodzą z lat 1513-1520 ${ }^{42}$. Kolejny, nieznany wcześniej odcisk odnalazł niedawno Sobiesław Szybkowski. Pieczęcią tą księżna regentka opatrzyła list do rady miasta Gdańska z 1 II $1516^{43}$.

S.K. Kuczyński założył, że pieczęć herbowa II była w użyciu księżnej Anny jedynie do końca jej rządów regencyjnych, zgodnie z brzmieniem wyroku Zygmunta I z 14 V $1518^{44}$. Kwestii, której pieczęci dotyczy przypuszczalnie owe orzeczenie królewskie, poświęcę nieco miejsca $\mathrm{w}$ dalszej części tekstu. Tu wypada zaznaczyć, że dwa jej odciski zachowane na listach z marca i listopada 1520 r. dowodzą, że Anna Radziwiłłówna używała jej nadal, również po ustaniu rządów opiekuńczych. Jak przypuszczam, księżna stosowała ją w związku ze sprawowaniem rządów w dobrach swego zaopatrzenia wdowiego, gdy wystawiała dokumenty, posługując się tytulaturą Anna Dei gracia dux Masouie, Russie etc., występującą na tym sigillum ${ }^{45}$. Fragmentaryczność zachowanego materiału źródłowego powoduje, że niemożliwa jest jednoznaczna odpowiedź na pytanie, czy pieczęć ta została czasowo wycofana z użycia w związku z dopuszczeniem książąt Stanisława i Janusza do współrządów w latach 1517-1518 i odsunięciem księżnej od władzy w maju 1518 r., tj. w czasie, gdy Anna powróciła do stosowania tytułu ducissa. Dowodnie od początku 1519 r. używała jednak ponownie męskiej formy tytułu książęcego - $d u x^{46}$, a zatem okres zawieszenia w stosowaniu objąłby hipotetycznie jedynie czas od wiosny 1517 do grudnia $1518 \mathrm{r}$. włącznie. Z drugiej strony, wycofanie z użytku tłoku pieczęci księżnej regentki po ustaniu jej rządów opiekuńczych nie znajduje analogii we wcześniejszej praktyce. Wykonanie nowej pieczęci specjalnie na potrzeby sprawowanej regencji przyjmuje się w przypadku księżnej Barbary Aleksandrówny, która w połowie 1458 r., po śmierci swej teściowej - Anny Bolkowej, objęła rządy w imieniu małoletnich Konrada, Kazimierza, Bolesława i Janusza, swoich synów z Bolesławem IV (zmarł w 1454) ${ }^{47}$. Po ustaniu rządów opiekuńczych w związku z dojściem najmłodszego z synów do pełnoletności i podziałem Księstwa Mazowieckiego między Bolesławowiców na sejmie w Zakroczymiu 3 IV 1471 Barbara nadal jej używała, zapewne aż do śmierci (zmarła przed 3 II 1492) ${ }^{48}$.

Osobista pieczęć herbowa nie była jedyną, którą księżna Anna posługiwała się w czasie swoich rządów regencyjnych. Do uwierzytelniania dokumentów o charakterze wieczystym dotyczących spraw publicznych państwa, wystawionych przez nią wspólnie z tutorami i dostojnikami Księstwa oraz razem z synami Stanisławem i Januszem, nadal używana była pieczęć średnia Konrada III Rudego. Wspominałam już o niej wyżej, dowodząc, że księżna użyła jej zapewne na liście do wielkiego mistrza krzyżackiego w lipcu 1505 r. (zob. s. 154). Pieczęcią tą opatrywano również dyplomy wydawane pod wyłącznym imieniem małoletnich książą ${ }^{49}$, z zachowaniem fikcji ich rządów. Znamy też jeden przypadek, gdy zabezpieczono nią dokument księżnej regentki, lecz był on realizacją woli zmarłego księcia ${ }^{50}$. Była to także pieczęć herbowa, okrągła, o średnicy $32 \mathrm{~mm}$. Jej wizerunek napieczętny zawierał herb księstwa

42 GStA PK, OBA, nr 19769 (14 V 1513; kredytywa dla Stanisława Dzierzgowskiego i Pawła Trębskiego, wystawiona wspólnie z małoletnimi książętami), 19954 (26 XII 1513), 20003 (12 I 1514), 20366 (9 II 1515), 20377 (23 II 1515), 21123 (9 XII 1516; kredytywa dla Pawła Trębskiego), 23303 (3 III 1520), 24385 [k. 4] (30 XI 1520).

${ }^{43}$ AP Gdańsk, Akta miasta Gdańska, Dokumenty i listy [dalej: AP Gdańsk, dok. i listy], 300 D/66, nr 183. Treść listu omawia S. Szybkowski, Korespondencja książą mazowieckich, s. 294, $301 \mathrm{n}$.

44 S.K. Kuczyński, Pieczęcie książat mazowieckich, s. 388, przyp. 9.

45 IMT 2, nr 215; tytulaturą tą posługiwała się również w listach, które wystawiała sama, tj. bez udziału synów: GStA PK, OBA, nr 22300, 22412, 23303, 24284.

46 GStA PK, OBA, nr 22300 (21 I 1519).

47 Pieczęcie księżnej Barbary, wraz z przypuszczalną chronologią ich używania, omawia S.K. Kuczyński, Pieczęcie książąt mazowieckich, s. 370 n. (nr 61, 62).

48 J. Grabowski, Dynastia Piastów mazowieckich, s. 362, 478; tenże, Poczet książąt i księżnych mazowieckich, Kraków 2019, s. 270-273. W przypadku pozostałych księżnych regentek z XV w. - Anny Bolkowej i Anny Władysławowej - wprowadzenie nowej pieczęci związanej z objęciem przez nie regencji nie jest jednoznacznie możliwe do stwierdzenia wobec szczupłości zachowanego materiału. To, czym obecnie dysponujemy, sugeruje raczej, że w obu przypadkach księżne używały nadal pieczęci sporządzonej dla nich w związku ze ślubem z księciem mazowieckim; por. S.K. Kuczyński, Pieczęcie książąt mazowieckich, s. 344 n., 358-360.

49 S.K. Kuczyński, Pieczęcie ksiażąt mazowieckich, s. 57 n., 388.

${ }^{50}$ AA Poznań, Acta episcopalia V, k. 96. 
czersko-warszawskiego: na tarczy czwórdzielnej w krzyż w polach naprzemianległych 1. i 4. - orzeł bez korony zwrócony w prawo, 2. i 3. - skrzydlaty smok na dwóch łapach zwrócony w prawo ${ }^{51}$. Legenda pieczęci zawierała imię księcia, formułę dewocyjną oraz tytulaturę ogólnomazowiecką i ruską ${ }^{52}$. Z okresu trwania regencji księżnej Anny zachowały się zaledwie cztery jej egzemplarze w całości ${ }^{53}$ i jeden we fragmencie ${ }^{54}$. Konrad III używał tej pieczęci również do poświadczania swoich listów ${ }^{55}$, natomiast w czasie małoletności jego synów nie stosowano jej już w tym celu. Traktowano ją wówczas jako pieczęć całego Księstwa Mazowieckiego, o niewątpliwie wyższej randze niż pieczęć osobista regentki ${ }^{56}$. O takiej jej funkcji i znaczeniu świadczy brzmienie formuł sigillacyjnych zapowiadających jej przywieszenie, szczególnie na dokumentach z pierwszego roku trwania regencji, dotyczących umów między Mazowszem a Królestwem Polskim: „In cuius rei testimonium sigillum mediocre ducatus Mazouie, quo nos Anna ducissa in rebus maioribus uti solemus" ${ }^{57}$; „sigillum mediocre ducatus Mazouie, quo nos Anna ducissa in rebus talibus utimur" 58 ; ,sigillum mediocre ducatus Mazouie, quo nos Anna ducissa prefata in maioribus rebus utimur" ${ }^{\prime 59}$. W najwcześniejszym znanym dokumencie księżnej regentki (z 11 III 1504), wystawionym wspólnie z jedenastoma członkami rady książęcej, podkreślono natomiast, że akt uwierzytelniony został pieczęcią zmarłego księcia Konrada, obecnie będącej w użyciu księżnej Anny ${ }^{60}$. Zapis o użyciu „pieczęci ojcowskiej” był następnie stałym elementem formuły sigillacyjnej dokumentów wystawianych w imieniu małoletnich książąt, która dość szybko przyjęła ustalone brzmienie: „In cuius rei testimonium sigillum mediocre paternum presentibus est appensum”ø1, choć często też nadawano jej

${ }^{51}$ Herb ten stanowił połączenie godła Piastów mazowieckich i całego Mazowsza (orzeł) z godłem dawnej dzielnicy czerskiej (smok). Na swoją pieczęć (herbową średnią) wprowadził go Janusz I. Pierwszy zachowany jej egzemplarz pochodzi z 1389 r., choć przypuszczalnie mogła powstać kilka lat wcześniej, tj. po 16 VI 1381, gdy po śmierci Siemowita III, na mocy nowego podziału Mazowsza z bratem Siemowitem IV, Januszowi przypadła ziemia czerska i wyszogrodzka. Po nim herb na pieczęci przejęli jego potomkowie, tj. Bolesław IV, potem najstarszy syn tegoż - Konrad III, a następnie wnuki Bolesława - Stanisław i Janusz III; S.K. Kuczyński, Pieczęcie książą mazowieckich, s. 165-168, 331, 363-369, 374, 388-392; J. Grabowski, Dynastia Piastów mazowieckich, s. 353 n.

52 S.K. Kuczyński, Pieczęcie książąt mazowieckich, s. 374 n., nr 64.

${ }^{53}$ Tylko jeden z nich to dokument wystawiony przez Annę z razem synami (AGAD, perg. nr 1547, 5 VI 1515; zob. <https:// szukajwarchiwach.pl/1/1/0/-/1547\#tabSkany> [dostęp: 21.03.2020]); pozostałe to dokumenty wystawione w imieniu małoletnich książąt Stanisława i Janusza III: AGAD, perg. nr 1548, 4 VIII 1515; Archiwum Klasztorne Jasna Góra, nr 86, 88, cyt. za: Zbiór dokumentów Zakonu Paulinów w Polsce, t. 2: 1464-1550, oprac. J. Zbudniewek, Warszawa 2004, nr 141 (20 VII 1508), 145 (4 VII 1509).

${ }^{54}$ AGAD, perg. nr 177.

55 GStA PK, OBA, nr 18069, 18362, 18487, 18526, 18590, 18644, 19241; S.K. Kuczyński, Pieczęcie książąt mazowieckich, s. 374, przyp. 9; S. Szybkowski, Korespondencja książat mazowieckich, s. 301.

${ }^{56}$ Opisany wyżej list księżnej Anny z lipca 1505 r. (GStA PK, OBA, nr 19019) jest jedynym znanym przypadkiem użycia pieczęci średniej Konrada III do uwierzytelnienia korespondencji w okresie po jego śmierci. Jak to zostało stwierdzone wyżej, owe wyjątkowe zastosowanie tego sigillum do zamknięcia listu wynikało zapewne z faktu, że księżna nie dysponowała jeszcze wówczas nową pieczęcią osobistą wykonaną na potrzeby sprawowania regencji.

${ }^{57}$ AGAD, perg. nr 156 (wyd.: IMT 2, nr 172). Przy tym dokumencie pieczęć książęca się nie zachowała; jedyną pozostałością jej przywieszenia jest pasek pergaminowy. Przetrwała jednak znakomita większość (sześć na siedem) pieczęci wojewody i kasztelanów mazowieckich, którzy wspólnie z regentką wystawili akt.

${ }^{58}$ AGAD, perg. nr 194 (wyd.: IMT 2, nr 175). Przy tym dokumencie również zachował się jedynie pasek pergaminowy, na którym przywieszona była pieczęć książęca, z pozostałych siedmiu należących do dostojników mazowieckich zachowały się wszystkie.

${ }^{59}$ AGAD, perg. nr 177 (wyd.: IMT 2, nr 176). Pieczęć książęca zachowana w ułomku; z czterech pieczęci tutorów zachowały się trzy, również we fragmentach.

${ }^{60}$ AGAD, perg. nr 178 (wyd. IMT 2, nr 170): „In quorum omnium fidem maiorem sigillum mediocre illustrissimi olim principis et domini Conradi Dei gracia Mazouie etc. ducis, domini nostri graciosissimi, quo nos Anna utimur...". Z pierwotnych dwunastu pieczęci zachowała się tylko jedna.

${ }^{61}$ Tak już w dokumencie małoletnich książąt z 20 I 1504 (AGAD, Zakr. 23, k. 183v) i w innych aktach z 1504 r.: AGAD, MK 18 , k. 234v, 250v, 260, 261v; AGAD, Zakr. 17, k. 426v, 471v; AGAD, perg. nr 6759 (tu ze słowem nostrum po sigillum) oraz późniejszych: AGAD, MK 32, k. 58, 70v, 204 (też: nostrum sigillum); AGAD, MK 18, k. 244v, 251; AGAD, Warszawskie ziemskie i grodzkie [dalej: Warsz.] 11, s. 542; AGAD, Zakr. 11, 467v; AGAD, Zakr. 19, k. 159v; AGAD, Zakr. 20, k. 442, 444, 670v. W najwcześniejszym znanym dokumencie małoletnich książąt z 8 XII 1503 formuła ta ma natomiast skrócone brzmienie: „In cuius rei testimonium sigillum nostrum paternum presentibus est appensum” (AGAD, MK 18, k. 210v). 
formę nieco bardziej rozbudowaną: „In cuius rei testimonium sigillum nostrum mediocre paternum, quo utimur, presentibus est appensum" ${ }^{2}$. Niekiedy jeszcze, zwłaszcza we wczesnym okresie rządów opiekuńczych, zaznaczano w niej nie tylko pokrewieństwo z Konradem, lecz i podawano jego pełną tytulaturę $^{63}$. W przypadku gdy dokument był wydawany przez niepełnoletnich Stanisława i Janusza wspólnie $\mathrm{z}$ matką, również informowano o uwierzytelnieniu go pieczęcią Księstwa Mazowieckiego ${ }^{64}$, natomiast w późniejszym czasie w formule tej anonsowano przywieszenie „średniej pieczęci książęcej”65. Pieczęcią tą przypuszczalnie uwierzytelniano też potwierdzane przez księżną dokumenty ${ }^{66}$. Zapewne też o niej mówi nagłówek rozpoczynający pod 1517 r. księgę rachunkową zawierającą rejestr długów książęcych ${ }^{67}$.

Do pieczętowania listów pisanych w imieniu własnym oraz własnym i małoletnich synów w trakcie sprawowania regencji księżna Anna używała natomiast zazwyczaj którejś z dwóch pieczęci herbowych sygnetowych zmarłego męża. Dzięki badaniom S.K. Kuczyńskiego znamy jeden z sygnetów Konrada III, ten o większych rozmiarach ${ }^{68}$. Jego odcisk zachował się w znakomitej większości omawianych tu listów. Dla precyzji dalszego wywodu przyjmujemy dla niego określenie ,sygnet I” (il. 3). Pierwszy znany list regentki uwierzytelniony tą pieczęcią pochodzi z 16 I $1504^{69}$. Miała ona formę ośmioboku o wymiarach 16,5 x 14,5 mm. W jej polu na tarczy znajdował się orzeł bez korony. Zamiast legendy nad tarczą umieszczono minuskulne gotyckie sygle $\mathrm{S}($ igillum $) \mathrm{C}$ (onradi). Pole pieczęci było otoczone podwójną linią otokową: zewnętrzną wydatną, wewnętrzną cienką i delikatnie zarysowaną ${ }^{70}$. Sylwetce orła nadano prostą formę, bez zaznaczania szczegółów, przedstawiając go ze skrzydłami ułożonymi w jednej linii, prostopadłej do boków tarczy. W sumie z czasu regencji księżnej Anny Radziwiłłówny znanych jest nam 15 listów opatrzonych sygnetem I księcia Konrada: 12 do członków zakonu krzyżackiego z lat 1504-1517¹,

${ }^{62}$ Zbiór dokumentów Zakonu Paulinów, t. 2, nr 145 (1509 r.); AGAD, MK 340, k. 60v (1512 r.); AGAD, MK 32, k. 1 (1517 r.), 21v (tu z końcówką: „est presentibus subappensum”, 1513 r.), 54 (1513 r.), 71v (1510 r.), 99 (1513 r.), 112 (1510 r.), 190v (1516 r.), 200v (1508 r.); AGAD, perg. nr 1528 (1515 r.); AGAD, Archiwum Potulickich z Obór, sygn. 1a, k. 40 (1516 r.); AGAD, Zakr. 11, 625 (1514 r.); czasem jednak z pominięciem słowa nostrum: Zbiór dokumentów Zakonu Paulinów, t. 2, nr 141 (1508 r.); AGAD, Zakr. 20, k. 441v (1506 r.); AGAD, MK 340 k. 75v (1512 r.); AGAD, MK 340, k. 75v (1517 r.); AGAD, Ziemskie błońskie 5, k. 169 (1511 r.); AGAD, Archiwum Potulickich z Obór, sygn. 1a, k. 47 (1511 r.); AGAD, MK 32, k. 20v (1512 r.), 117 (1516 r.), 214v (1513 r.); AGAD, Warsz. 10, s. 1137 (1512 r.).

${ }^{63}$ AGAD, MK 32, k. 2 = AGAD, MK 340, k. 79: „,in cuius rei testimonium sigillum mediocre illustrissimi olim principis et domini domini Conradi Dei gracia ducis Mazovie Russie etc. felicis memorie patris nostri charissimi presentibus est appensum" (15 III 1504).

$64,[\ldots]$ sigillum mediocre ducatus Masoviae”: akt księżnej i jej synów z 2 XI 1504, potwierdzający nadanie dla kościoła w Łomży, druk: J. Grabowski, Dynastia Piastów mazowieckich, Aneks I, nr 24; poświadczenie książąt dotyczące ustanowienia opieki z 11 X 1505 (AGAD, Księgi ziemskie tarczyńskie, 5, k. 94v); poświadczenie dla Serafina i Marty Mallerów mieszczan warszawskich (AGAD, Warsz. 10, s. 1266; 1512 r.).

${ }^{65}$ AGAD, perg. nr 1547, „In cuius rei testimonium sigillum nostrum mediocre ducale, quo utimur, presentibus est subappensum" (wyd.: Przywileje królewskiego miasta stołecznego Starej Warszawy 1376-1772, wyd. T. Wierzbowski, Warszawa 1913, nr 28). W grudniu 1517 r. w brzmieniu: „In cuius rei testimonium sigillum nostrum mediocre, quo presentibus utimur, est appensum"; AGAD, MK 32, k. 122

${ }^{66} 16$ VI 1511 przed obliczem sądu nadwornego odbywanego w Osiecku zjawił się Arnold z Chrostowa z dokumentem księcia Janusza II dotyczącym przepadku (lapsus) tegoż Chrostowa i prosił księżną, „ut litteras prefatas illustrissima domina dux roborare sigillo mediocri aut in metricam perpetuitam introducere facere digneretur”, na co Anna zezwoliła (,in librum curie ducalis domina dux introducere fecit”); AGAD, MK 340, k. 54v.

${ }^{67}$ AGAD, MK 340, k. 1: „Registrum debitorum ducalium litteris mediocris sigilli obligatoriis 1517”; zob. też: tamże, k. 73, tu wzmianka z 1518 r. o przedstawieniu w sądzie wypisu „ex registro thesaurarii iudiciorum curie sub sigillo ducali extraditum”.

68 S.K. Kuczyński, Pieczęcie książat mazowieckich, s. 375 n., nr 65.

${ }^{69}$ GStA PK, OBA, nr 18879.

${ }^{70}$ S.K. Kuczyński, Pieczęcie książąt mazowieckich, s. 375, nr 65; zob. też J. Grabowski, Dynastia Piastów mazowieckich, s. 370. S. Szybkowski, omawiając odcisk tego sygnetu zachowany na liście książęcym do rajców gdańskich, podaje, że wyryte na nim sygle są majuskulne; tenże, Korespondencja książąt mazowieckich, s. 301.

${ }^{71}$ GStA PK, OBA, nr 18879, 18905, 19177, 19185, 19221, 19486, 19752a, 19920, 21061, 21077, 21082, 21255. S.K. Kuczyński (tenże, Pieczęcie książą mazowieckich, s. 376, przyp. 5) notuje z tego archiwum pięć pewnych przypadków użycia (do nr. 19221 włącznie). Badacz nie uwzględnił jednak nr. 18905. Uważał natomiast, że omawianym sygnetem księżna Anna opatrzyła list z 8 VI 1504 (GStA PK, OBA, nr 18916). Z autopsji wiadomo jednak, że list ten uwierzytelniono mniejszym sygnetem Konrada; zob. niżej. 
dwa do gdańskiej rady miejskiej z 1508 i $1515 \mathrm{r}^{72}$ oraz jeden do toruńskiej rady miejskiej z $1505 \mathrm{r}^{73}$ Wliczam w to jedynie te listy, na których znajdują się odciski, a stan ich zachowania nie budzi wątpliwości, której pieczęci użyto do ich zamknięcia ${ }^{74}$.

Do uwierzytelniania korespondencji regentka stosowała również mniejszy sygnet Konrada III, będę go określać jako sygnet II (il. 4). Pieczęć ta nie była znana S.K. Kuczyńskiemu. Jako pierwszy zwrócił na nią uwagę S. Szybkowski, analizując listy ostatnich Piastów mazowieckich zachowane w Archiwum Państwowym w Gdańsku. Badacz ten zauważył, że dwa listy księżnej Anny z 1515 r. opieczętowane zostały „nieznanym dotąd drugim sygnetem Konrada III, o nieco mniejszym od dotychczas znanego"75. Jego wymiary określił na ok. 14 x $11 \mathrm{~mm}$. Stwierdził również, że sygnet ten cechuje lepiej, pod względem artystycznym, wykonany wizerunek orła bez korony, a sygle $\mathrm{S} * \mathrm{C}$ wyryto na nim majuskułą humanistyczną ${ }^{76}$. W zasobie OBA zachowały się trzy listy księżnej regentki do wielkiego mistrza krzyżackiego, które opatrzyła ona owym drugim, mniejszym sygnetem zmarłego męża. Pierwszy z nich pochodzi z pierwszego roku rządów regencyjnych (8 VI 1504) ${ }^{77}$, dwa pozostałe zaś z ich okresu końcowego (5 V i 15 VII 1516) ${ }^{78}$. Po przeprowadzeniu autopsji do opisu zamieszczonego przez S. Szybkowskiego dodać można uwagę, że sygnet II miał również formę ośmioboku, a jego pole było otoczone pojedynczą linią otokową. Znajdujące się nad gotycką tarczą sygle S C umieszczono w większym odstępie niż na znanej dotąd pieczęci sygnetowej księcia, dodając między nimi dywizor w formie kropki. W porównaniu do sygnetu I wizerunek napieczętny został nie tylko wykonany z większą artystyczną dbałością, lecz widoczne są także różnice w wyglądzie sylwetki orła - przedstawiono go tu z lekko uniesionymi skrzydłami.

W znanej mi korespondencji Konrad III ani razu nie posłużył się sygnetem II ${ }^{79}$. Okres, z którego pochodzą znane jego odciski, tj. lata 1504-1516, rodzi zatem wątpliwość, czy nie został on sporządzony na krótko przed śmiercią Konrada III, a zaczął być szerzej stosowany dopiero w czasie regencji sprawowanej w imieniu jego małoletnich synów. Na późne wykonanie tłoku wskazywać zdaje się zastosowanie na nim liternictwa wczesnorenesansowego, niepojawiającego w sfragistyce książąt mazowieckich przed początkiem XVI w. ${ }^{80}$ Pierwsze znane dotychczas sigilla, na których je zastosowano, to dwie wspólne pieczęcie książąt Stanisława i Janusza III wykonane w 1518 r., gdy po zniesieniu opieki ich matki objęli oni samodzielne rządy: herbowa średnia ${ }^{81}$ oraz sygnetowa ${ }^{82}$. Wykonanie kolejnej pieczęci sygnetowej dla Konrada związane było przypuszczalnie z jednej strony z zużyciem się tłoka sygnetu I, będącego w użyciu przypuszczalnie od $1471 \mathrm{r}^{83}$, a z drugiej, z chęcią posiadania nowej pieczęci, odpowiadającej pod względem stylu aktualnie obowiązującym prądom artystycznym. Po objęciu władzy w imieniu małoletnich synów księżna Anna, zwłaszcza w początkowym okresie swoich rządów, znacznie częściej posługiwała się sygnetem I swego zmarłego męża niewątpliwie dlatego, że był on dużo lepiej

72 AP Gdańsk, dok. i listy, 300 D/6, nr 336, 395; S. Szybkowski, Korespondencja książąt mazowieckich, s. 301.

${ }^{73}$ AP w Toruniu, Akta miasta Torunia, kat. I, dokumenty i listy, nr 2672/3.

${ }^{74} \mathrm{Na}$ trzech listach księżnej regentki widoczny jest jedynie woskowy ślad po użytym sygnecie; GStA PK, OBA, nr 18910, 21279; AP Toruń, Akta miasta Torunia, kat. I, dokumenty i listy, nr 2754/C. Pod uwagę wzięłam tu materiał do marca 1517 r. włącznie.

75 S. Szybkowski, Korespondencja książąt mazowieckich, s. 302; chodzi o listy o sygnaturach: AP Gdańsk, dok. i listy, 300 D/6, nr 397; 300 D/80, nr 131.

${ }^{76}$ S. Szybkowski, Korespondencja książą mazowieckich, s. 302.

77 GStA PK, OBA, nr 18916. Na opieczętowanie tegoż listu nieznanym dotąd sygnetem Konrada III zwrócił uwagę S. Szybkowski, Korespondencja książą mazowieckich, s. 302, przyp. 151. Odcisk jest obecnie uszkodzony i słabo czytelny.

78 GStA PK, OBA, nr 20851, 20953.

${ }^{79}$ Kwerendą objęto zespół OBA, tu listy opatrzone pieczęcią średnią (zob. przyp. 55) oraz sygnetową I (GStA PK, OBA, nr 18304, 18308, 18314, 18319, 18545, 18642, 18643, 18654, 18750, 18828, 18830); korespondencję przechowywaną w AP w Gdańsku przebadał S. Szybkowski.

${ }^{80}$ S.K. Kuczyński, Pieczęcie książąt mazowieckich, s. 209 n., 243 n.

81 Tamże, s. 388 n., nr 77.

82 Tamże, s. 390, nr 78. O przypuszczalnym czasie wprowadzenia wspólnego sygnetu Stanisława i Janusza do użytku będzie mowa niżej.

${ }^{83}$ Tamże, s. 376. 
„rozpoznawalny” niż mniejszy sygnet, będący w krótkim (być może zaledwie kilkumiesięcznym) użytkowaniu Konrada. Stosowanie przez Annę Radziwiłłównę równolegle obu sygnetów zmarłego księcia wynikać mogło natomiast ze specyfiki rządów regencyjnych, gdy korespondencja prowadzona były zarówno przez księżną regentkę, jak i (choć sporadycznie) pod imieniem małoletniego władcy ${ }^{84}$. Okoliczności wymuszały zaś niekiedy sytuacje, że niepełnoletni książęta przebywali z dala od matki ${ }^{85}$. Współistnienie dwóch sygnetów mogło być formą zabezpieczenia na takie przypadki: jeden zabierała ze sobą regentka, drugi zostawał z jej synami. Szczupłość zachowanych źródeł (w tym brak materiału porównawczego z poprzednio sprawowanych regencji) nie pozwala jednak na zweryfikowanie tego twierdzenia i musi ono pozostać w sferze hipotez.

Którymś z sygnetów Konrada III księżna regentka pieczętowała nie tylko swą korespondencję, lecz także przypuszczalnie wszystkie wystawiane mandaty i pozwy kierowane do urzędników sądów ziemskich lub starostów. Kilka tego rodzaju pism zachowało się dzięki wszyciu do ksiąg sądowych, niestety na większości pozostał jedynie ślad po odcisku pieczęci (w czerwonym wosku) ${ }^{86}$. Z brzmienia zapisów wynika, że pieczęcią sygnetową księżna regentka uwierzytelniała również niektóre dokumenty, dowodnie te poświadczające czynność prawną o określonym czasie obowiązywania. W lutym 1510 r. mieszczanin warszawski Serafin przedstawił w sądzie „litteram ducalem papiream sub signeto ducali tempore per decursum anni durante", zwalniające go od stawiennictwa przed sądem ${ }^{87} .6$ III 1514 księżna opieczętowała sygnetem dokument wystawiony przez nią jako dux et tutrix Masovie Russie etc. i zezwalający Stanisławowi Wąsowskiemu na użytkowanie dóbr książęcych do czasu uzyskania pełnoletności przez małoletnich książąt, co stwierdzała odpowiednia formuła sigillacyjna: „In cuius rei fidem signetum nostrum ducalem, quo utimur, presentibus est impressum" "88. Sygnetem umacniano też z reguły wypisy z metryki książęcej ${ }^{89}$. Do zapisu przytoczonego przez S.K. Kuczyńskiego na dowód, że reskrypt dokumentu z 1504 r. ${ }^{90}$ opieczętowano właśnie sygnetem Konrada III, uczynić wypada uwagę, że adnotacja na tymże reskrypcie, mówiąca, że został on „sub signeto parvo extraditum”, zamieszczona w edycji dokumentu w kodeksie wydanym przez Jana Tadeusza Lubomirskiego, nie podaje daty jego sporządzenia ${ }^{91}$. Odnosić się zatem może np. do sygnetu książąt Stanisława i Janusza, który stosowali oni w latach 1518-1524, po dojściu do pełnoletności.

Ostatni stwierdzony przeze mnie przypadek użycia przez Annę Radziwiłłównę pieczęci sygnetowej zmarłego męża pochodzi z 9 III 1517, gdy księżna posłużyła się większym sygnetem Konrada III do

${ }^{84}$ Przykładem mogą być listy Bolesława IV pochodzące z okresu, gdy rządy regencyjne sprawowała jego matka Anna Bolkowa (1434 r.) do władz zakonu krzyżackiego (GStA PK, OBA, nr 6844, 6855) i rajców gdańskich (S. Szybkowski, Korespondencja książą mazowieckich, „Regesty” nr 3, 5).

${ }^{85}$ Przykładowo, wiadomo, że na sejmie w Zakroczymiu, który obradował w kwietniu i maju 1504 r., obecna była jedynie księżna Anna, mali książęta przebywali wówczas w Warszawie; AGAD, MK 18, 234v; M. Piber-Zbieranowska, Księżna mazowiecka Anna Radziwiłłówna, Aneks I: Itinerarium ks. Anny Radziwiłłówny (1503-1518), s. 518.

${ }^{86}$ AGAD, Zakr. 11, między k. 369v i 370 (ślad po odcisku sygnetu; 1509 r.); AGAD, Zakr. 19, między k. 312 a 317 (ślad; 1509 r.); AGAD, Zakr. 21, między k. 319v-320 a k. 337 (odcisk uszkodzony; 1515 r.); po k. 578v (odcisk większego sygnetu; 1516 r., wspólnie z synami); między k. 639v-640 (dobrze zachowany odcisk większego sygnetu; 1517 r., wspólnie z synami). Pieczęcie sygnetowe używane przez książąt do uwierzytelniania pism doraźnych nie stanowiły dotąd przedmiotu szerszych badań. O fakcie stosowania „pieczęci średniej lub sygnetu” do poświadczania pism o charakterze doczesnym, w tym również mandatów, wspomina w jednym zdaniu J. Grabowski, Kancelarie ksiązęce na Mazowszu (do 1526 roku), w: Dyplomatyka staropolska, red. T. Jurek, Warszawa 2015, s. 236. Na pogłębioną analizę czeka również formularz tego rodzaju pism. Wstęp do niej stanowić może kilkuzdaniowy akapit, który poświęcił mandatom i ich formularzowi wspomniany badacz (tamże).

87 AGAD, Warsz. 10, s. 249.

${ }^{88}$ AGAD, MK 340 k. 47v-48.

89 A. Wolff, Metryka Mazowiecka. Układ pierwotny. Sposób rejestracji, Warszawa 1929, s. 79. Na wniosek kanclerza Mikołaja Żukowskiego na sejmie w Zakroczymiu w lipcu 1519 r. uchwalono sporządzenie specjalnego sygnetu do wypisów z metryki, opatrzonego syglami SMPT, stanowiącymi skrót jego nazwy: Sigillum Metricae Perpetuitatum Terrestrium. Ponieważ nieznane są żadne odciski tej pieczęci, nie wiadomo, czy ostatecznie wprowadzono ją do użytku; IMT 2, nr 221; S.K. Kuczyński, Pieczęcie książąt mazowieckich, s. 392 n., nr 81; J. Grabowski, Kancelarie książęce, s. 245.

90 Pochodzącego oryginalnie z księgi AGAD, MK 18, k. 189v-190.

${ }^{91}$ KDMaz., nr 277, s. 330. Podstawą wydania był dla J.T. Lubomirskiego opieczętowany wypis z metryki książęcej, znajdujący się w momencie opublikowania tomu kodeksu (tj. w 1863) w Archiwum Magistratu miasta Warszawy. 
uwierzytelnienia mandatu (wystosowanego wspólnie z synami) skierowanego do urzędników sądu ziemskiego w Zakroczymiu ${ }^{92}$. Być może opieczętowała nim również list do wielkiego mistrza z 16 III 1517, na którym widoczny jest jedynie ślad po użyciu pieczęci sygnetowej. Jego rozmiary - 19 x $17 \mathrm{~mm}-$ sugerować mogą, że i w tym wypadku księżna użyła większego z omówionych wyżej sygnetów ${ }^{93}$. Wbrew hipotezom S.K. Kuczyńskiego, który sądził, że sygnet Konrada III był w użyciu do maja 1518 r. ${ }^{94}$, przypuszczam, że uchwycony źródłowo moment - marzec 1517 r. - odpowiada rzeczywistości i po tym czasie oba sygnety zmarłego księcia nie były już stosowane. Kwerenda w zespole OBA znajdującym się obecnie w GStA PK przyniosła bowiem nieoczekiwany efekt: odnalezienie dwóch nieznanych dotąd pieczęci sygnetowych należących wspólnie do księżnej Anny i jej synów - Stanisława i Janusza, o czym świadczą majuskulne sygle A S I widoczne na ich odciskach, odpowiadające inicjałom książąt. Na obu obraz napieczętny jest analogiczny jak na sygnecie księcia Konrada: orzeł na tarczy zwrócony w prawo. Sygnety te różnią się jednak między sobą istotnymi szczegółami.

Pierwszy z nieznanych dotąd sygnetów ma kształt owalny i jest znacznie większy niż stosowany poprzednio sygnet I księcia Konrada III - jego wymiary wynoszą 25 x 19 mm (il. 5). Na rozwijanej wstędze nad tarczą umieszczono majuskulne sygle tworzące legendę: A(nna) S(tanislaus) I(anussius) / $\mathrm{D}$ (uces) $\mathrm{M}$ (azovie) $\mathrm{R}($ ussie). Zastosowane liternictwo ma już cechy pisma humanistycznego. Wykonano je kapitałą protorenesansową: nad literą A z prawej strony znajduje się charakterystyczna dla tego pisma pozioma nasadka (daszek), laska litery I jest pośrodku przełamana ${ }^{95}$. Wyraźnie odmienny od dotychczas spotykanych jest również kształt tarczy - wczesnorenesansowy, o profilowanych krawędziach. Górna krawędź tarczy oraz boki są ozdobnie wygięte, dół zaś ma lekko wyciągnięty języczek ${ }^{96}$. Po obu stronach tarczy, w wycięciach znajdują się pojedyncze ozdobne elementy roślinne (fleurony). Widoczny na tarczy orzeł ma rozpostarte, wysoko uniesione skrzydła, z wyraźnie zaznaczonymi lotkami. Boczne pióra na jego ogonie są ozdobnie podkręcone do wewnątrz. Pole pieczęci otoczono podwójną obwódką: zewnętrzną wydatną perełkową i wewnętrzną wąską ciągłą. Sygnetu tego użyto dowodnie do zamknięcia czterech listów książąt do wielkiego mistrza krzyżackiego oraz do uwierzytelnienia listu kredencyjnego dla książęcego posła. Jego odciski, w różnym stanie zachowania, widoczne są w listach pochodzących z okresu od $13 \mathrm{~V}$ do 2 X $1517^{97}$. Zastosowanie nowej pieczęci sygnetowej zbiega się w czasie z powrotem księżnej regentki do stosowania tytułu ducissa, co związane było z dopuszczeniem do współrządów starszego z synów - Stanisława, który w tym czasie ukończył już 15. rok życia, i rezygnacją księżnej Anny z części posiadanej władzy na rzecz obu synów. Księżna przestała występować

92 AGAD, Zakr. 21, między k. 639v i 640; w mandacie zastosowano tytulaturę w brzmieniu: Anna dux et tutrix, Stanislaus et Joannes Dei gracia duces Mazouie Russie etc.

93 GStA PK, OBA, nr 21279; list napisany wspólnie z synami. W liście tym księżna użyła już tylko tytułu ducissa, do którego powróciła po dopuszczeniu starszego syna do wspólnych rządów. W świetle obu tych źródeł przypuszczać możemy, że nastąpiło to między 9 a 16 III 1517; zob. niżej.

94 S.K. Kuczyński, Pieczęcie książą mazowieckich, s. 376.

95 B. Trelińska, Gotyckie pismo epigraficzne w Polsce, Lublin 1991, s. 93 n., 99. Liternictwo zastosowane na omawianym sygnecie zaliczyć możemy do, wyróżnionego przez B. Trelińską, typu pisma protorenesansowego, określanego jako kapitała orientalna lub grecka (inaczej też gotycko-renesansowa); tamże, s. 111 n.; zob. też taż, Epigraficzna kapitała protorenesansowa $w$ Polsce, w: Tradycje i perspektywy nauk pomocniczych historii w Polsce. Materiaty z sympozjum w Uniwersytecie Jagiellońskim dnia 21-23 października 1993 profesorowi Zbigniewowi Perzanowskiemu przypisane, red. M. Rokosz, Kraków 1995, s. 209-228.

${ }^{96}$ Kształt górnej części tarczy jest identyczny jak na pieczęci średniej Stanisława i Janusza III używanej przez nich od 1518 r., którą pod względem stylu S.K. Kuczyński zaliczył do pieczęci wczesnorenesansowych. Opisując kształt znajdującej się na niej tarczy, badacz ten stwierdził, że ,nie jest to jeszcze wykształcony renesansowy kartusz herbowy o zwijanych krawędziach, lecz forma tarczy, która go poprzedziła”; tenże, Pieczęcie książąt mazowieckich, s. 243.

${ }^{97}$ GStA PK, OBA, nr 21347, 21352, 21371, 21386 (kredytywa dla Andrzeja Zakrzewskiego), 21542. Być może pieczęci tej użyto już w liście księżnej i jej synów z 2 V 1517 (GStA PK, OBA, nr 21341), choć zachował się tu jedynie ślad po użytym sygnecie, co uniemożliwia stwierdzenie tego w sposób pewny. Nie zachowała się również pieczęć w liście Anny, Stanisława i Janusza wysłanym do wielkiego mistrza 7 VII 1517 z Bielska, w czasie ich podróży do Wilna (GStA PK, OBA, nr 21422). Rozmiar śladu po odciśniętej pieczęci - 24 x $22 \mathrm{~mm}$ - pozwala podejrzewać z dużym prawdopodobieństwem, że posłużono się tu omawianym sygnetem. 
już jako ich tutrix, choć najpewniej jeszcze do schyłku lata 1517 r. sprawowała jakąś formę opieki nad młodszym synem Januszem ${ }^{98}$. Wpływ na tę decyzję miała bardzo napięta sytuacja wewnętrzna w Księstwie, wywołana działaniami części szlachty opozycyjnie nastawionej do dalszych rządów księżnej regentki oraz związana z tym interwencja dyplomatyczna króla polskiego. Podjęte przez księżną kroki miały uspokoić sytuację i być sui generis kompromisem, który pozwoliłby jej jeszcze zachować część władzy. Sądzić można zatem, że wykonanie nowego sygnetu miało odzwierciedlać nowy stan polityczny w Księstwie, w którym dotychczasowe rządy opiekuńcze księżnej Anny przekształcono we wspólne rządy matki i synów. Sygle umieszczone na nowej pieczęci odpowiadały również tytulaturze, którą książęta posługiwali się na omawianych listach: Anna ducissa, Stanislaus et Ianussius Dei gracia duces Mazovie Russie etc.

Cztery kolejne listy książąt mazowieckich do wielkiego mistrza Albrechta Hohenzollerna, pochodzące z lutego i marca 1518 r., opatrzono innym sygnetem, mniejszym od poprzedniego, także owalnym (il. 6) ${ }^{99}$. Jego wymiary wynoszą $20 \times 15 \mathrm{~mm}$. Wizerunek napieczętny jest tu skromniejszy - nad tarczą $\mathrm{z}$ orłem bezpośrednio $\mathrm{w}$ polu pieczęci umieszczono jako legendę pisane majuskułą sygle $+\mathrm{A}$ S I + . Analogicznie jak na wyżej omówionym sygnecie, wykonano je kapitałą protorenesansową. Krój litery A jest niemal identyczny jak tam - z poziomą nasadką na górze, tu nieznacznie opadającą; laskę litery I przełamano na środku. Górna krawędź tarczy i jej boki są ozdobnie wygięte, jednak dużo mniej wydatnie niż na większym sygnecie. Nieco inny jest również dół tarczy: zakończony bardziej półokrągło, z nieznacznie zaznaczonym języczkiem. Wizerunek orła jest zaś bardzo zbliżony, jeśli chodzi o przedstawienie skrzydeł i ogona. Różnicę widać natomiast w układzie głowy - tu lekko uniesionej, z zadartym dziobem, zapewne po to, by zmieścić na głowie orła nakrycie przypominające kształtem mitrę książęcą ${ }^{100}$. Podobnie też jak poprzednio, pole pieczęci otacza podwójna obwódka: na zewnątrz perełkowa, a wewnątrz wąska ciągła.

Z braku większej liczby odcisków obu wspomnianych sygnetów nie można jednoznacznie stwierdzić, jaka była zależność między nimi. Hipotez może być kilka. To, że odciski większego sygnetu pochodzą tylko z okresu marzec - październik 1517 r., mniejszego natomiast dopiero z pierwszych miesięcy 1518 r., może być jedynie dziełem przypadku. Przyjęcie takiego założenia prowadziłoby do konstatacji, że oba sygnety powstały w tym samym czasie (tj. wiosną 1517 r., gdy Anna dopuściła Stanisława do współrządów) i używano ich zamiennie, być może na podobnej zasadzie jak wcześniej sygnetu I i II księcia Konrada. Przesłanką do takiego twierdzenia może być fakt, że książę Stanisław zabrał dowodnie większy sygnet ze sobą na wyprawę przeciw Wielkiemu Księstwu Moskiewskiemu, w której towarzyszył królowi Zygmuntowi I we wrześniu i październiku 1517 r. ${ }^{101}$ Jego matka i brat przebywali wówczas w Wilnie ${ }^{102}$ i, jak przypuszczam, musieli mieć przy sobie własną pieczęć do uwierzytelniania pism

98 Janusz urodził się najpewniej w końcu sierpnia lub na początku września 1502 r.; K. Jasiński, Rodowód Piastów mazowieckich, s. 204. Wiek sprawny osiągnął zatem późnym latem $1517 \mathrm{r}$.

${ }^{99}$ GStA PK, OBA, nr 21740 (3 II 1518), 21747 (10 II 1518), 21781 (7 III 1518), 21795 (13 III 1518). Pierwsze dwa listy napisane są przez księżną Annę i jej synów, trzeci tylko przez Stanisława, a ostatni przez Stanisława i Janusza, bez udziału matki. Mniejszym wspólnym sygnetem księżnej i jej synów mógł być uwierzytelniony również list Anny, Stanisława i Janusza do gdańskiej rady miejskiej, wystosowany 25 II 1518 (AP Gdańsk, dok. i listy, 300 D/6, nr 425; list omawia S. Szybkowski, Korespondencja książąt mazowieckich, s. 295, podając jednak błędną datę - 1 II 1518; jego opinia na temat użytej pieczęci zob. tamże, s. 302). Pieczęć przy nim się nie zachowała, lecz użycie tego sygnetu uprawdopodabnia fakt, że książęta posłużyli się nim dwa tygodnie wcześniej na liście do Albrechta Hohenzollerna (GStA PK, OBA, nr 21747).

100 Takie przedstawienie orła powtórzono w zasadzie bez modyfikacji na wspominanym wyżej wspólnym sygnecie Stanisława i Janusza, wprowadzonym do użytku po objęciu przez nich samodzielnych rządów w 1518 r.; zob. niżej. Opisując go, S.K. Kuczyński wyraził przypuszczenie, że orła przedstawiono w mitrze; tenże, Pieczęcie książąt mazowieckich, s. 390 , nr 78.

${ }^{101}$ Działania wojenne prowadzone były na wschodnich rubieżach Wielkiego Księstwa Litewskiego, w rejonie Połocka i Brasławia; K. Pacuski, Stanisław (1501-1524), ksiąze mazowiecki, s. 1; GStA PK, OBA, nr 21542: list księcia Stanisława do wielkiego mistrza Albrechta Hohenzollerna napisany 2 X 1517 z Brasławia. Fakt zabrania przez Stanisława większego sygnetu ze sobą na wyprawę wojenną z królem świadczyć może, że to on był głównym dysponentem tej pieczęci, mimo że formalnie miała ona trzech użytkowników.

102 M. Piber-Zbieranowska, A. Supruniuk, Regencja Anny Radziwitłówny, s. 343; M. Piber-Zbieranowska, Księżna mazowiecka Anna Radziwiłłówna, Aneks I: Itinerarium ks. Anny Radziwiłłówny (1503-1518), s. 530. 
i listów. Nie można też jednak odrzucić hipotezy, że mniejszy sygnet sporządzono dopiero po powrocie księżnej i jej synów z podróży litewskiej na Mazowsze w grudniu 1517 r. ${ }^{103}$ i zastąpiono nim poprzednią wspólną pieczęć, używaną do tej pory. Wiązać to można by z dojściem przez księcia Janusza III do pełnoletności i wynikającym z tego faktu dalszym ograniczeniem władzy jego matki. Przesłanką do takiego twierdzenia może być przedstawienie napieczętne tegoż sigillum, na którym wprowadzono niewielką, lecz dość istotną zmianę merytoryczną poprzez umieszczenie na głowie orła mitry. Podkreślać to miało zapewne fakt, że książęta sprawują władzę samodzielnie i suwerennie ${ }^{104}$.

O tym, że do końca trwania regencji w użytku były jednak zapewne oba omówione wyżej sygnety, wnioskować możemy z brzmienia wyroku Zygmunta I z 14 V 1518. Na jego mocy nastąpiło formalne odsunięcie księżnej Anny Radziwiłłówny od władzy i ostateczne ustanie jej opieki nad synami. Decyzję królewską zatwierdzić miał następnie sejm mazowiecki wyznaczony na 29 czerwca $^{105}$. W wyroku król polecał książętom Stanisławowi i Januszowi, by na tymże sejmie zniszczyli „sigilla suum et matris suae dominae Annae, nomen et titulum continentia” oraz unieważnili „litteras sub illis datas”. Zaznaczał też, że on sam, na ile to leży w jego gestii, wspomniane pieczęcie i dokumenty niniejszym pozbawia mocy prawnej ${ }^{106}$. Analiza zapisu nasuwa dwie refleksje. Po pierwsze, użyta tu liczba mnoga świadczy, że orzeczenie królewskie dotyczyło przynajmniej dwóch różnych pieczęci. S.K. Kuczyński uważał, że w królewskim wyroku mowa jest o osobistej pieczęci herbowej księżnej regentki. Nie sposób się jednak z tym zgodzić, biorąc pod uwagę odciski tej pieczęci zachowane na listach księżnej Anny z 1520 r., świadczące, że pieczęć ta była nadal w użytku księżnej, także i po zakończeniu regencji. Co do wymienionych tu pieczęci młodych książąt badacz ów przypuszczał zaś, że „z uwagi na to, że w latach niesprawnych nie posiadali oni własnych pieczęci, ustęp ten może odnosić się do pieczęci średniej Konrada III" ${ }^{107}$. Zastanawiać się można jednak, czy wówczas nie zostałoby jakoś zaznaczone, że orzekającemu chodzi o pieczęć ojca książąt. Istotnie, w późniejszym okresie rządów regencyjnych pieczęć tę określano czasem tylko jako sigillum mediocre ducale, lecz znacznie częściej zaznaczano, że użyta została pieczęć ojcowska. W świetle odkrycia dwóch wspólnych pieczęci sygnetowych księżnej i jej synów należy według mnie przyjąć, że rozporządzenie króla dotyczyło niewątpliwie właśnie tych pieczęci. Obie „zawierały imiona książąt i ich matki” (jak stwierdza to wyraźnie wyrok królewski), większa zaś również i skróconą tytulaturę. Po drugie, z tenoru dyspozycji króla Zygmunta zdaje się wynikać, że ostatecznego unieważnienia pieczęci i wystawionych pod nimi dokumentów mieli dokonać Stanisław i Janusz Konradowice na sejmie mazowieckim. Orzeczenie króla stanowiło polecenie, by tak uczynić, co, w mojej ocenie, nie stwarzało jeszcze obowiązującej Mazowszan mocy prawnej. Król pozbawiał owe pieczęcie i pisma ważności, lecz sam zaznaczał, że czyni to „quantum in nobis est”. Nie mamy niestety żadnych wiadomości źródłowych, czy na sejmie obradującym od 29 czerwca do 4 lipca w Zakroczymiu postąpiono zgodnie z zaleceniem królewskim i zarządzono unieważnienie i zniszczenie wspólnych pieczęci księżnej i jej synów.

Na miejsce pieczęci średniej Konrada III książęta Stanisław i Janusz, objąwszy pełnię władzy w Księstwie, sprawili sobie własną pieczęć średnią, znacznie bardziej okazałą (jej średnica wynosiła $58 \mathrm{~mm}$ ), wizerunkiem napieczętnym nawiązującą do pieczęci ich ojca i dziada ${ }^{108}$. Pierwszy zachowany jej odcisk pochodzi dopiero z 29 IX $1518^{109}$, choć przypuszczalnie jej tłok został wykonany jeszcze

${ }^{103}$ M. Piber-Zbieranowska, Księżna mazowiecka Anna Radziwiłłówna, Aneks I: Itinerarium ks. Anny Radziwiłłówny (1503$-1518)$, s. 530.

${ }^{104}$ Mitra na głowie orła pojawiła się potem na wspólnej pieczęci herbowej średniej Stanisława i Janusza III (zob. wyżej, przyp. 96) oraz na pieczęci średniej Janusza III, sporządzonej po śmierci jego brata w 1524 r.; S.K. Kuczyński, Pieczęcie książąt mazowieckich, s. 390 n., nr 79. Omówienie zagadnienia wprowadzenia do herbowej symboliki mazowieckiej mitry książęcej (chronologia, geneza, zasięg, kontekst), niepodjętego przez dotychczasową literaturę przedmiotu, wykracza poza ramy niniejszego tekstu. Autorka zamierza poświęcić mu odrębne studium.

105 IMT 2, nr 208; B. Sobol, Sejm i sejmiki, s. 130-132.

106 „Quae quidem [...] sigilla et litteras nos, quantum in nobis est, cassamus et in irritum vertimus”; IMT 2, nr 208.

107 S.K. Kuczyński, Pieczęcie książą mazowieckich, s. 388, przyp. 9.

108 Zob. wyżej, przyp. 51. Opis pieczęci: S.K. Kuczyński, Pieczęcie książąt mazowieckich, s. 243 n., 388 n., nr 77.

109 AGAD, perg. nr 1017. 
przed rozpoczęciem obrad sejmu zakroczymskiego, wkrótce po otrzymaniu przez książąt wyroku króla Zygmunta z 14 maja. W mandacie książęcym dla starosty łomżyńskiego Pawła Brzeskiego, nakazującym mu zastosowanie się do postanowienia książąt i ich doradców dotyczącego podatku od cechu słodowników w Łomży, wystosowanym na tymże sejmie 4 lipca, zanotowano, że został on wydany „sub sigillo ducali”"10. W świetle wspomnianego orzeczenia królewskiego polecającego książętom, by właśnie na tymże sejmie znieśli oni moc prawną i zniszczyli dotychczas stosowane pieczęcie, trudno zakładać, że po ogłoszeniu tego typu decyzji Stanisław i Janusz opatrzyli swój dokument dawną, dopiero co unieważnioną pieczęcią. Datę postanowienia królewskiego jako czas a quo wykonania nowej pieczęci przyjął S.K. Kuczyński ${ }^{111}$. Datę a quo wprowadzenia jej do użytku wyznacza zaś, moim zdaniem, początek obrad sejmu w Zakroczymiu, tj. 29 czerwca.

Do użytku wprowadzono też nowy sygnet herbowy Stanisława i Janusza III. Były na nim wyryte majuskulne sygle + S I +, oznaczające pierwsze litery imion młodych władców (il. 7). W polu pieczęci umieszczono, wzorem poprzednio używanych sygnetów książęcych, na tarczy orła, w tym przypadku w mitrze. Sygnet, o wymiarach 18 x 14 mm, miał owalny kształt ${ }^{112}$. S.K. Kuczyński zakładał, że wykonanie sygnetu i jego wejście w użycie zbiegało się w czasie z wprowadzeniem do praktyki kancelaryjnej nowej pieczęci średniej książąt, zatem miało to miejsce około połowy $1518 \mathrm{r} .{ }^{113} \mathrm{Na}$ podstawie argumentów sformułowanych wyżej można sądzić, że o użyciu tegoż sygnetu wspominają już dwa mandaty książęce wydane na sejmie w Zakroczymiu 4 VII 1518, co stwierdzała formuła „sub signeto ducali": 1) dla Andrzeja Zaliwskiego kasztelana wiskiego i starosty nurskiego ${ }^{114}$, 2) dla Krystyna z Kubry starosty kolneńskiego ${ }^{115}$. Pierwszy znany dotąd odcisk tegoż sygnetu, odnotowany przez wykaz zestawiony przez S.K. Kuczyńskiego, pochodził jednak dopiero z 12 IV 1522. Został on umieszczony na liście księcia Stanisława do rady miasta Gdańska ${ }^{116}$. Sporządzenie sygnetu w 1518 r. można obecnie potwierdzić. Udało mi się bowiem odnaleźć nieznany wcześniej odcisk sygnetu Stanisława i Janusza Konradowiców pozostawiony na liście do Albrechta Hohenzollerna z 5 X 1518, napisanym wspólnie przez księżną Annę i jej synów ${ }^{117}$. Z zachowanego w zespole OBA w GStA PK materiału wynika również, że omawiana pieczęć sygnetowa służyła nie tylko samym Konradowicom do uwierzytelniania korespondencji sporządzanej w imieniu własnym bądź razem z matką, lecz także posługiwała się nią księżna Anna, gdy samodzielnie wystawiała listy już po ustaniu regencji118. Ostatni z takich listów, podpisany: „Anna genitrix Stanislaus et Johannes Dei gracia duces Mazouie, Russie etc.”, napisano $10 \mathrm{~V}$ 1521 w książęcym dworku myśliwskim w Osiecku ${ }^{119}$.

Przedstawiona powyżej analiza pozwala stwierdzić, że w ciągu niemal piętnastoletnich rządów regencyjnych w użytku księżnej Anny Radziwiłłówny było w sumie aż siedem różnych pieczęci: dwie osobiste herbowe I i II, trzy odziedziczone po zmarłym mężu Konradzie III Rudym - średnia herbowa i dwa sygnety (większy i mniejszy) oraz dwa sygnety (większy i mniejszy) wspólne księżnej

${ }^{110}$ AN, Oddział I, Zbiór Zygmunta Glogera, t. 45, s. 281-283; por. B. Sobol, Sejm i sejmiki, s. 129. Zastanawiać jedynie może, dlaczego pieczęci średniej użyto do uwierzytelnienia mandatu, gdyż, jak wspomniano wyżej, zazwyczaj posługiwano się w takich wypadkach sygnetem. Wydany na tym samym sejmie i z tą samą datą (4 VII 1518) dokument Stanisława i Janusza, najwcześniejszy znany po ich usamodzielnieniu, przypuszczalnie również uwierzytelniony został tą pieczęcią. Zachował się on jednak jedynie w skróconym wpisie do ksiąg ziemskich błońskich; AGAD, Ziemskie błońskie 4, k. 767-769v: „Ingrossacio litterarum ducalium Cholevi”, bez formuły sigillacyjnej.

111 S.K. Kuczyński, Pieczęcie książą mazowieckich, s. 389.

112 Opis pieczęci: tamże, s. 390, nr 78.

113 Tamże, s. 390, przyp. 3.

114 AN, Oddział I, Zbiór Zygmunta Glogera, t. 45, s. 277 n. Książęta napominali w nim Zaliwskiego, by nie pobierał więcej bezprawnie cła od mieszczan łomżyńskich, ponieważ posiadają oni przywilej książęcy.

115 Wiadomość o tym mandacie podaje B. Sobol (tenże, Sejm i sejmiki, s. 129), wg Kapicjanów. Mandat był w tej samej sprawie, jak ten wystosowany do A. Zaliwskiego.

116 AP Gdańsk, dok. i listy, 300 D/6, nr 507a; S.K. Kuczyński, Pieczęcie książąt mazowieckich, s. 390, przyp. 2; list ten omawia S. Szybkowski, Korespondencja książat mazowieckich, s. 295 n., 302.

117 GStA PK, OBA, nr 22133.

118 GStA PK, OBA, nr 22300, 22301, 22375, 22412, 22619, 24845, 25392, 25462, 25488, 25724.

119 GStA PK, OBA, nr 24845. 
i jej synów Stanisława i Janusza III pochodzące z czasu, gdy zostali oni dopuszczeni do władzy. Tak duża liczba pieczęci wynikała ze specyfiki formy rządów, jaką była regencja, i związanej z tym większej różnorodności pism wychodzących z kancelarii książęcej - dokumentów o charakterze doczesnym i listów wystawianych przez księżną regentkę samodzielnie, we własnym imieniu i uwierzytelnianych jej osobistą pieczęcią, dyplomów wieczystych publikowanych z zachowaniem fikcji rządów małoletnich książąt, opatrywanych pieczęcią średnią zmarłego księcia oraz pism doraźnych - mandatów i rozporządzeń książęcych, a także korespondencji, do których stosowano zazwyczaj sygnety. Dwie nieznane do tej pory pieczęcie sygnetowe należące wspólnie do książąt Anny, Stanisława i Janusza, pochodzące z krótkiego okresu współrządów matki i synów (1517-1518), stanowią rzecz właściwie bez precedensu w sfragistyce Piastów mazowieckich, w której do początku XVI w. nie występowały wspólne pieczęcie ani trzech, ani nawet dwóch władców sprawujących rządy w niedziale bądź współrządzących ${ }^{120}$.

${ }^{120}$ Zob. uwagi (w tym również przytoczone analogie ze sfragistyki obcej) S.K. Kuczyńskiego do hipotetycznej wspólnej pieczęci synów Kazimierza II Sprawiedliwego - Leszka Białego i Konrada I; tenże, Pieczęcie książą mazowieckich, s. 257-259. 


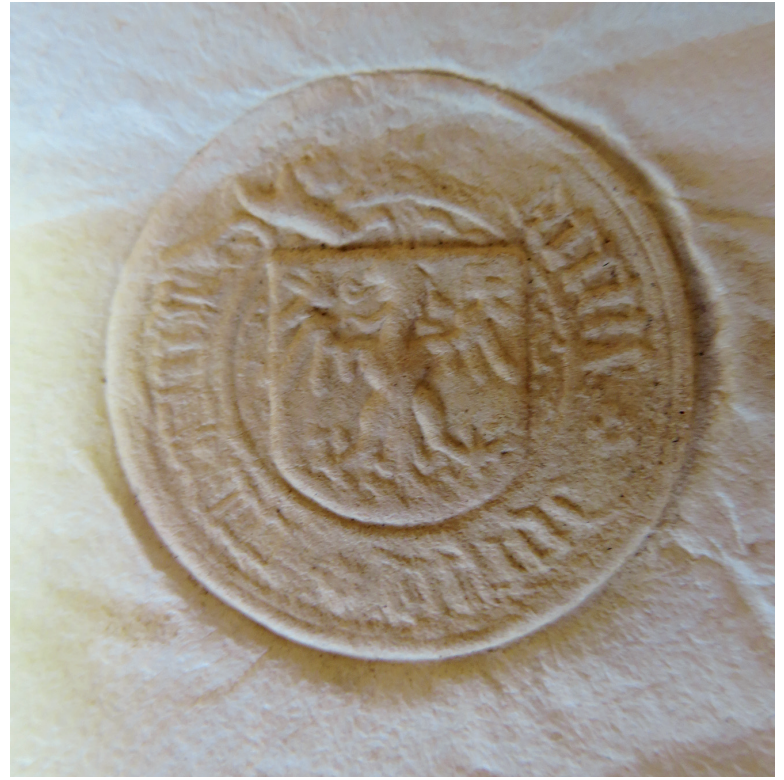

Il. 1. Pieczęć herbowa I księżnej Anny Radziwiłłówny; GStA PK, OBA, nr 18848, fot. M. Piber-Zbieranowska

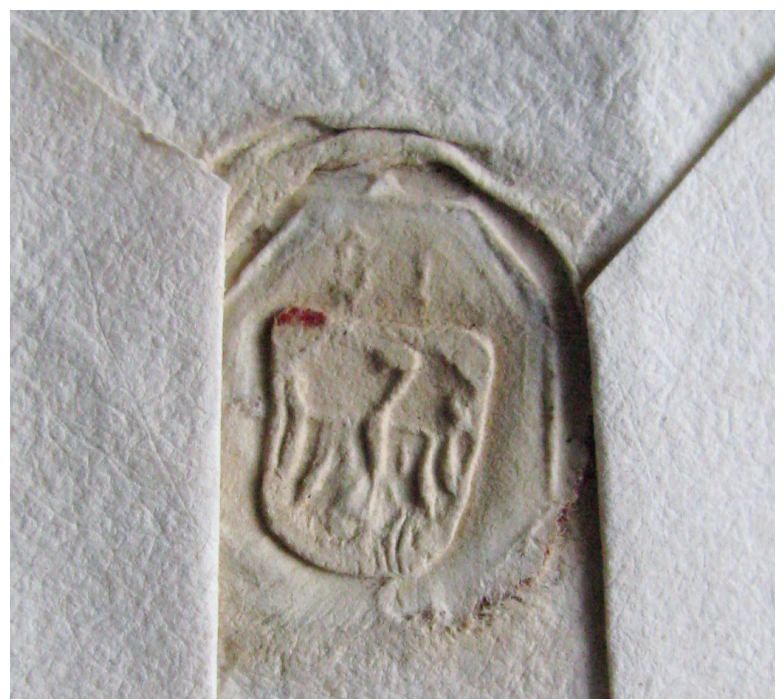

Il. 3. Pieczęć sygnetowa I księcia Konrada III Rudego; AGAD, Zakroczymskie ziemskie wieczyste relacje, nr 21, między k. 639v-640, fot. M. Piber-Zbieranowska

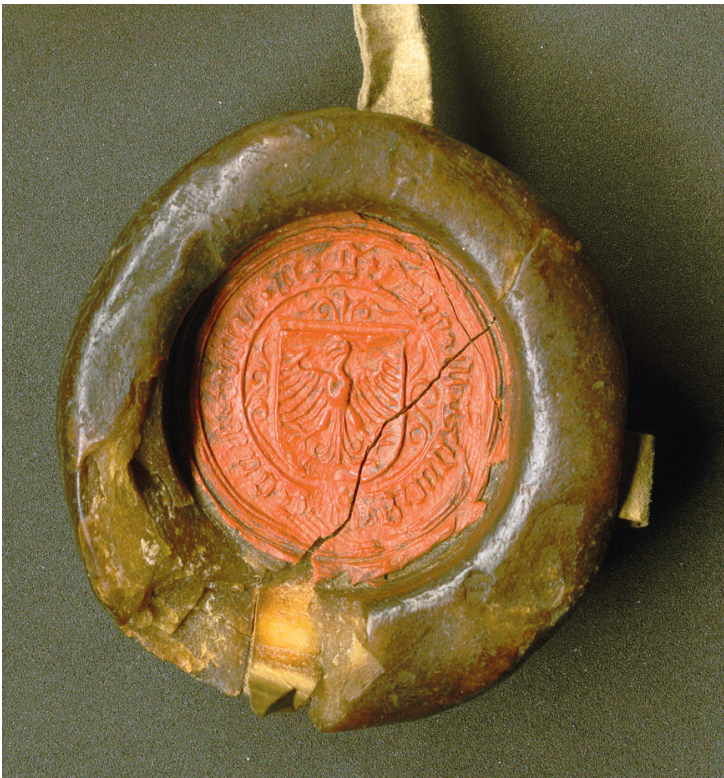

I1. 2. Pieczęć herbowa II księżnej Anny Radziwiłłówny; AGAD, Zbiór dokumentów pergaminowych, sygn. 1545, fot. M. Wręczycka

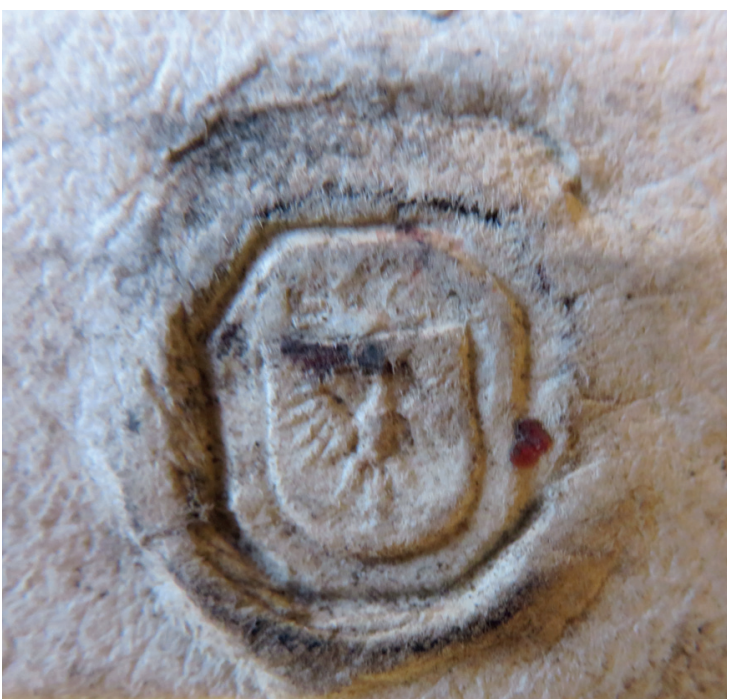

I1. 4. Pieczęć sygnetowa II księcia Konrada III Rudego; GStA PK, OBA, nr 20953, fot. M. Piber-Zbieranowska 


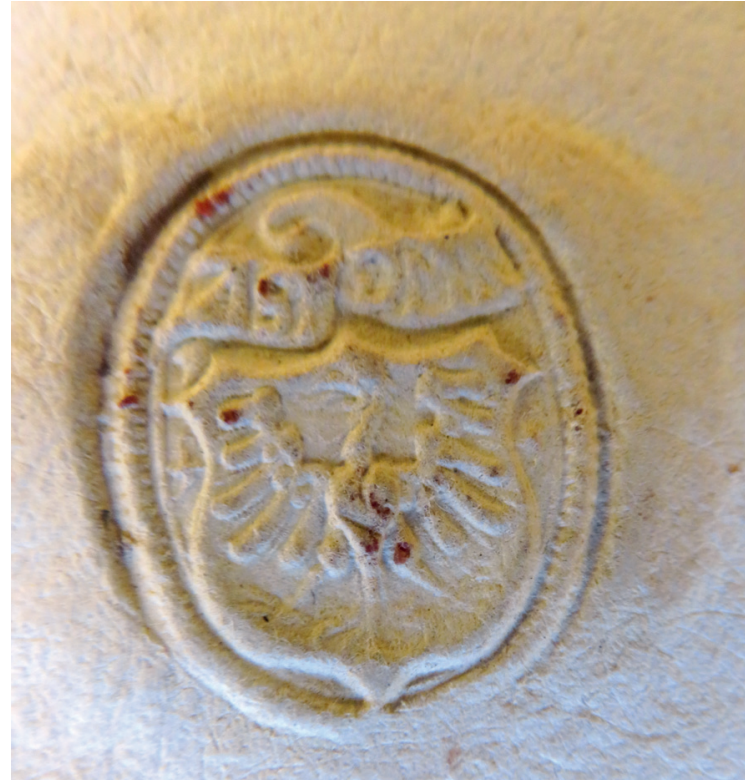

Il. 5. Pieczęć sygnetowa większa książąt Anny, Stanisława i Janusza; GStA PK, OBA, nr 21347, fot. M. Zbieranowski

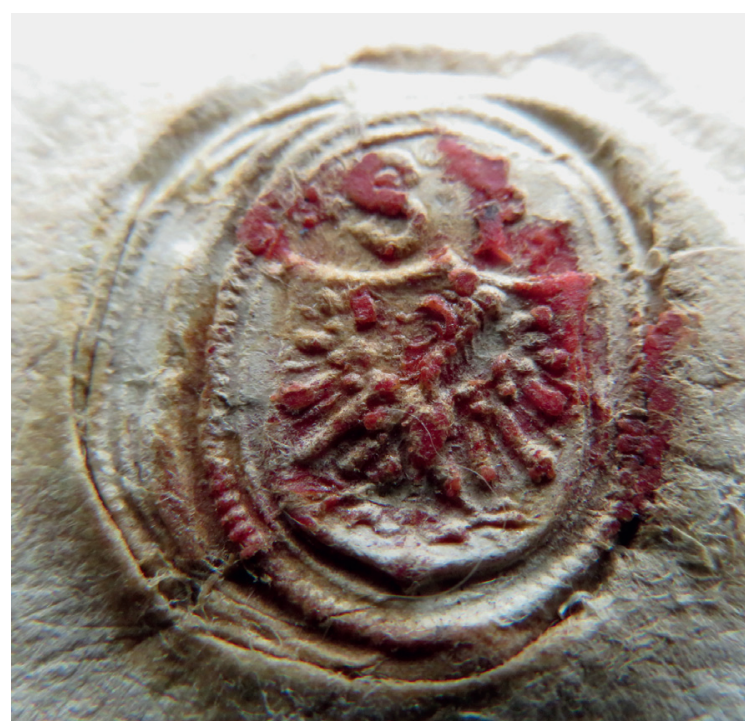

I1. 7. Pieczęć sygnetowa książąt Stanisława i Janusza III; GStA PK, OBA, nr 22375, fot. M. Zbieranowski

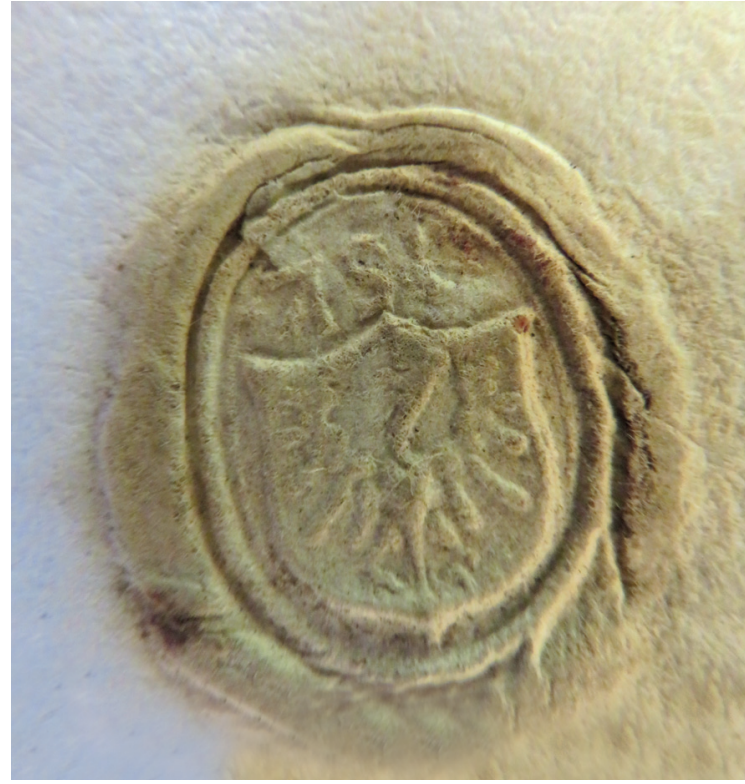

Il. 6. Pieczęć sygnetowa mniejsza książąt Anny, Stanisława i Janusza; GStA PK, OBA, nr 21781, fot. M. Zbieranowski 


\title{
The seals of Anna Radziwill, Duchess of Mazovia from her regency in Mazovia in 1503-1518
}

\begin{abstract}
Summary: The article discusses the seals used by Anna Radziwiłł, Duchess of Mazovia, the widow of Konrad III the Red, during her almost fifteen years of regency on behalf of her underage sons - Stanisław and Janusz. Throughout the analysed period (1503-1518), she used seven different seals: two personal armorial seals I and II, three inherited from her deceased husband Duke Konrad III the Red - the medium armorial and two signet seal (a bigger and smaller one), and two signet seals (a bigger and smaller) belonging jointly to the duchess and her sons made at the time when they were admitted to power and co-rule with their mother (1517-1518). Such a large number of seals resulted from the specificity of the regency and greater variety of documents issued by the ducal chancellery - documents of a temporal nature and letters issued by the Duchess Regent independently, on her own behalf, and approved with her personal seal with the inscription Anna Dei gracia dux Mazovie, Russie; perpetual diplomas published with the preservation of the fiction of the rule of the minor dukes, i.e. sealed with the medium seal of their deceased father, and temporary writs - mandates and ducal decrees, as well as correspondence, usually sealed with signets. Two signet seals belonging jointly to the duchess and her sons, with the initials ASI, have been previously unknown. They were discovered during the search query at the Geheimes Staatsarchiv Preußischer Kulturbesitz in Berlin-Dahlem in the Ordensbriefarchiv. This is the only case in the sphragistics of the Mazovian Piast, when one seal was at the disposal of three persons, jointly ruling in the duchy. The discovery of new seals made it possible to shift the time of use by Duchess Anna of her personal armorial seal made for her regency. So far, it has been assumed that the seal was revoked and destroyed after the regency ended in 1518. The two seal prints on the Duchess' letters to the Grand Master of the Teutonic Order written in March and November 1520 allow us to suppose that Anna Radziwiłł used this seal until her death in March 1522, issuing documents and carrying out the correspondence necessary to manage the estates within her dower.
\end{abstract}

Nota o autorze: Marta Piber-Zbieranowska, mgr historii, pracownik naukowy Instytutu Historii im. Tadeusza Manteuffla Polskiej Akademii Nauk, w latach 1998-2012 w Zakładzie Atlasu Historycznego, od 2012 r. w Zakładzie Słownika Historyczno-Geograficznego Ziem Polskich w Średniowieczu. Specjalizuje się w dziejach średniowiecznego i wczesnonowożytnego Mazowsza oraz geografii historycznej Polski i historii kartografii. Jej zainteresowania badawcze koncentrują się również wokół kobiecych rządów regencyjnych w średniowiecznej Polsce i politycznej roli kobiet w tym okresie. Dysertacja, będąca aktualnie przedmiotem postępowania w przewodzie doktorskim, poświęcona jest regencji księżnej Anny Radziwiłłówny.

Author: Marta Piber-Zbieranowska, MA, researcher at the Tadeusz Manteuffel Institute of History, Polish Academy of Sciences, in 1998-2012 in the Department of Historical Atlas, since 2012 in the Department of the Historical-Geographical Dictionary of the Polish Lands in the Middle Ages. She specialises in the history of settlement of late-medieval and early modern Mazovia, also in the historical geography of Poland and in the history of cartography. She is also especially interested in the female regent government in the medieval Polish lands and in the political role of women in this period. Her doctoral thesis, currently the subject of proceedings, concerns the regency of Duchess Anna Radziwiłł of Mazovia.

Instytut Historii im. Tadeusza Manteuffla

Polska Akademia Nauk

ul. Rynek Starego Miasta 29/31

00-272 Warszawa

e-mail: mpiber@ihpan.edu.pl

\section{Bibliografia}

\section{Źródła}

Iura Masoviae terrestria, t. 2: 1471-1526, oprac. J. Sawicki, Warszawa 1973

Kodeks dyplomatyczny Księstwa Mazowieckiego, wyd. J.T. Lubomirski, Warszawa 1863

Przywileje królewskiego miasta stołecznego Starej Warszawy 1376-1772, wyd. T. Wierzbowski, Warszawa 1913

Regesta historico-diplomatica Ordinis S. Mariae Theutonicorum, cz. 1: Regesten zum Ordensbriefarchiv, t. 2:

1455-1510, t. 3: 1511-1525, oprac. E. Joachim, wyd. W. Hubatsch, Göttingen 1950, 1973 
Wzory pism dawnych $w$ przerysach wystawione i objaśnione drukowanem ich wyczytaniem, cz. 1: 1228-1536, wyd. K. Stronczyński, Warszawa 1839

Zbiór dokumentów Zakonu Paulinów w Polsce, t. 2: 1464-1550, oprac. J. Zbudniewek, Warszawa 2004

\section{Opracowania}

Biskup M., Materiały do stosunków habsbursko-mazowieckich na przełomie XV-XVI w. w archiwach austriackich, Przegl. Hist., 59, 1968, nr 2, s. 272-279

Dziedzictwo ksiażat mazowieckich. Stan badań i postulaty badawcze. Materiały z sesji naukowej zorganizowanej przez Zamek Królewski w Warszawie - Muzeum i Archiwum Główne Akt Dawnych, 27-28 października 2016 r., red. J. Grabowski, R. Mroczek, P. Mrozowski, Warszawa 2017

Grabowski J., Dynastia Piastów mazowieckich. Studia nad dziejami politycznymi Mazowsza, intytulacja i genealogia ksiązat, Kraków 2012

Grabowski J., Kancelarie książęce na Mazowszu (do 1526 roku), w: Dyplomatyka staropolska, red. T. Jurek, Warszawa 2015, s. 213-252

Grabowski J., Matżeństwa Konrada III Rudego. Ze studiów nad genealogia Piastów mazowieckich, w: Klio viae et invia. Opuscula Marco Cetwiński dedicata, red. A. Odrzywolska-Kidawa, Warszawa 2010, s. 799-808

Grabowski J., Tytulatura na dokumentach książat mazowieckich. Forma i funkcje (wybrane zagadnienia), „Klio”, 13, 2009, s. 41-79

Halecki O., Anna z Radziwittów (1476-1522), księżna mazowiecka, w: PSB, t. 1, Kraków 1935, s. 125 n.

Jasiński K., Rodowód Piastów mazowieckich, wyd. M. Górny, Poznań-Wrocław 1998 [recte: 2008]

Kuczyński S.K., Pieczęcie ksiażat mazowieckich, Wrocław 1978

Pacuski K., Stanistaw (1501-1524), ksią̇ę mazowiecki, w: PSB, t. 42, Warszawa-Kraków 2003-2004, s. 1-3

Piber-Zbieranowska M., Księżna mazowiecka Anna Radziwittówna i jej regencja na Mazowszu (1503-1518), Warszawa 2019, mszp. rozprawy doktorskiej przyg. pod kier. M. Koczerskiej, Biblioteka IH PAN w Warszawie

Piber-Zbieranowska M., Żony Piastów mazowieckich. Znaczenie polityczne księżnych w późnym średniowieczu (XIV-XVI w.), w: Dziedzictwo książat mazowieckich. Stan badań i postulaty badawcze. Materiaty z sesji naukowej zorganizowanej przez Zamek Królewski w Warszawie - Muzeum i Archiwum Główne Akt Dawnych, 27-28 października 2016 r., red. J. Grabowski, R. Mroczek, P. Mrozowski, Warszawa 2017, s. 127-138

Piber-Zbieranowska M., Supruniuk A., Die Legitimierung der Herrschaft in Masowien im Lichte der Urkunden und Korrespondenz der masowischen Herzogin Anna Radziwittówna, w: Legitimation von Fürstendynastien in Polen und dem Reich. Identitätsbildung im Spiegel schriftlicher Quellen (12.-15. Jahrhundert), red. G. Vercamer, E. Wółkiewicz, Wiesbaden 2016, s. 319-348

Piber-Zbieranowska M., Supruniuk A., Regencja Anny Radziwitlówny na Mazowszu w latach 1503-1518: zarys problematyki, Przegl. Hist., 106, 2015, nr 2, s. 325-345

Sobol B., Konrad III (ok. 1448-1503), ksiązę mazowiecki, w: PSB, t. 13, Poznań-Wrocław 1967-1968, s. 595-597

Sobol B., Sejm i sejmiki ziemskie na Mazowszu ksiązęcym, Warszawa 1968

Szybkowski S., Korespondencja ksiażą mazowieckich z rada miasta Gdańska w latach 1466-1526, w: Dziedzictwo książą mazowieckich. Stan badań i postulaty badawcze. Materialy z sesji naukowej zorganizowanej przez Zamek Królewski w Warszawie - Muzeum i Archiwum Główne Akt Dawnych, 27-28 października 2016 r., red. J. Grabowski, R. Mroczek, P. Mrozowski, Warszawa 2017, s. 283-303

Trelińska B., Epigraficzna kapitała protorenesansowa w Polsce, w: Tradycje i perspektywy nauk pomocniczych historii w Polsce. Materiały z sympozjum w Uniwersytecie Jagiellońskim dnia 21-23 października 1993 profesorowi Zbigniewowi Perzanowskiemu przypisane, red. M. Rokosz, Kraków 1995, s. 209-228

Trelińska B., Gotyckie pismo epigraficzne w Polsce, Lublin 1991 